\title{
Seasonal and inter-annual dynamics of coccolithophore fluxes from the upwelling region off Cape Blanc, NW Africa
}

\author{
M.I. Koebrich*, K.-H. Baumann \& G. Fischer \\ Department of Geosciences, University of Bremen, PO Box 330440, 28334 Bremen, Germany \\ *Correspondence: meral.koebrich@gmail.com
}

\begin{abstract}
Coccolithophore fluxes were determined at a mooring site off Cape Blanc ( $\left.21^{\circ} 08.7^{\prime} \mathrm{N}, 20^{\circ} 41.2^{\prime} \mathrm{W}\right)$ from March 1989 to November 1991 to reveal inter-annual and seasonal changes in species composition. In total, 74 coccolithophore species were recorded, with Emiliania huxleyi, Florisphaera profunda and Gephyrocapsa spp. dominating the assemblage. Two major conditions were identified, leading to three different intervals with characteristic species composition and associated changing environmental factors: a 'normal' condition characterized by fluctuating fluxes with rather constant species assemblage and a 'pulse-like event' that reveals a significant increase in coccolithophore fluxes and change in species composition. From March 1988 to October/November 1990 and from May 1991 the coccolithophore assemblage was dominated by E. huxleyi, F. profunda, G. flabellatus, G. oceanic, and G. ericsonii. Variability within this assemblage points to the occurrence of different surface waters, such as offshore meandering filaments. In winter 1990/1991 a 'pulse-like event' followed that was characterized by a significant increase in coccolithophore fluxes and in the contribution of species of the genera Ophiaster, Acanthoica, Calciosolenia, Calciopappus and Syracosphaera. It is assumed that a fast settling took place after enhanced production occurred. The third interval from May to November 1991 displays reduced fluxes of all coccolithophore species. However, the species composition is similar to the first interval, thus seemingly the assemblage converges back to 'normal' conditions. Statistical analysis revealed small correlations of the tested environmental parameters, such as sea surface temperature, nutrient availability and lithogenic fluxes. Nevertheless a certain seasonality of the assemblages was obvious in terms of different correlation of these environmental factors. In autumn the variability of the coccolithophorid assemblage is correlated more to sea surface temperature, whereas the spring assemblage of coccolithophores is related more to nutrient availability. In contrast, the summer assemblage is, to some extent, influenced by all tested environmental factors, suggesting that further environmental parameters are more important. This may also explain that although the observed mean coccolith fluxes off Cape Blanc are well within the range of those in the SW African upwelling, as well as in more oligotrophic sites of the temperate North Atlantic and the Canary Islands, the assemblage composition is conspicuously different. The region off Cape Blanc stands out in terms of a lesser content of $E$. huxleyi but an enhanced proportion of a number of small-sized coccolithophore species.
\end{abstract}

Keywords: Cape Blanc; sediment trap; coccolithophores; fluxes; inter-annual variability

Received 23 September 2014; accepted 18 December 2014

Coccolithophores are pelagic unicellular golden-brown algae that are widely distributed in the world's oceans. They are unusual because they are capable of fixing carbon by both photosynthesis for organic matter production and calcification for $\mathrm{CaCO}_{3}$ crystal (coccolith) formation (Westbroek et al. 1993). Their ocean-wide distribution makes them probably the most important calcifying organisms on Earth. The export of coccoliths to the deep floor occurs mainly via faecal pellets and contributes greatly to carbonate deposition in sediments (Honjo 1976; Turner 2002; Baumann et al. 2004; Fischer et al. 2007; Ziveri et al. 2007). In addition, coccolithophores have remarkable value as palaeoenvironmental indicators (Baumann et al. 2005) and were therefore used as indicators of surface water mass changes, often with particular emphasis on primary productivity variations (e.g. Kinkel et al. 2000; Baumann et al. 2005; Incarbona et al. 2010). Furthermore, shifts in species composition observed in several sediment cores were attributed to changes in upwelling and eddy formation or frontal zone movements (Winter \& Martin 1990). A basic prerequisite for such palaeoenvironmental and palaeoceanographic reconstructions is knowledge of the modern ecological adaptations of coccolithophore species. Sediment traps are invaluable in this respect, both to determine coccolith export fluxes over long time periods and to reveal seasonal and inter-annual differences (Haidar et al. 2000; Ziveri et al. 2000; Dutkiewicz et al. 2001; Romero et al.
2002; Sprengel et al. 2002; Ramaswamy \& Gaye 2006; Stoll et al. 2007).

The main aim of the present study is to evaluate the environmental factors influencing settling coccolithophore assemblages in the high-production area off Cape Blanc, induced by coastal upwelling. For this purpose, sediment trap material from a threeyear mooring site was investigated in terms of species composition and abundance. Relationships between coccolithophore fluxes and environmental conditions of the overlying surface waters, as well as the potential effects of lithogenic particles, were deduced. In addition, the significance of coccolithophore production is assessed by comparing the assemblage composition and fluxes of the study area with other upwelling and non-upwelling areas of the Atlantic.

\section{Oceanographic setting}

The mooring site $\left(21^{\circ} 08.7^{\prime} \mathrm{N}, 20^{\circ} 41.2^{\prime} \mathrm{W}\right)$ is located within the filamentous mixing area of the coastal upwelling off Cape Blanc (Fig. 1), one of the prominent Eastern Boundary Upwelling Systems (EBUS). The surface oceanography of the region is strongly influenced by the southward-flowing Canary Current (CC), the eastern branch of the subtropical gyre, which detaches from the continental slope between $25^{\circ} \mathrm{N}$ and $21^{\circ} \mathrm{N}$ and flows southwestwards supplying the North Equatorial Current (NEC) 


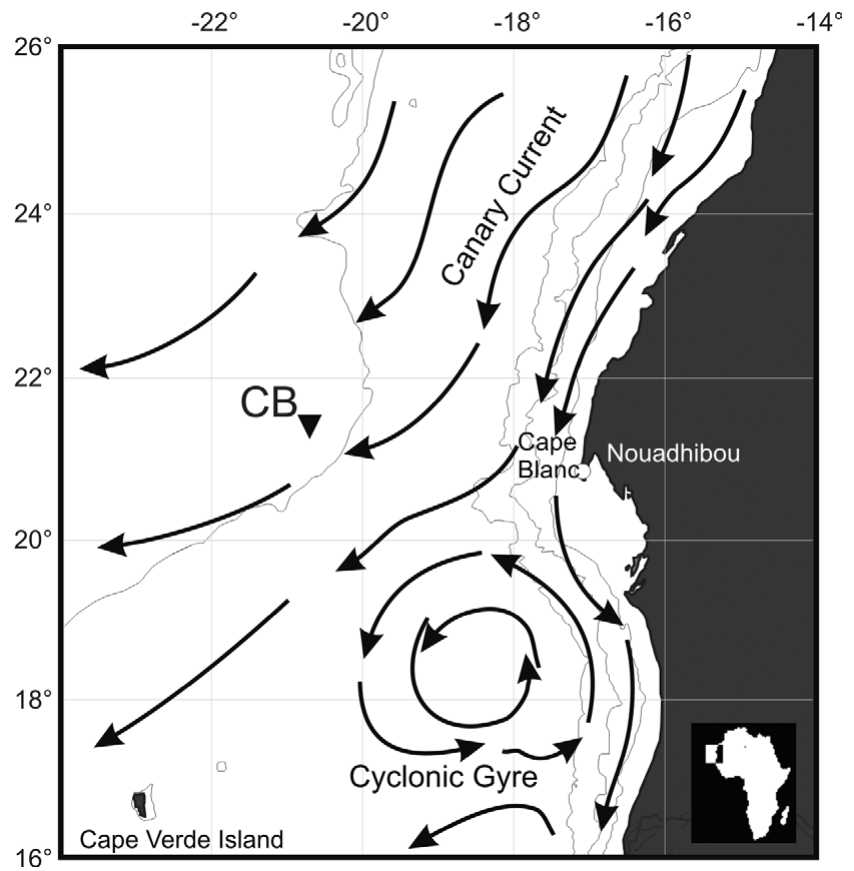

Fig. 1. Mooring location (CB) and principal features of the surface oceanography off NW Africa (modified after Mittelstaedt 1991).

(Fig. 1). Its surface waters are relatively cool because as it travels south it entrains upwelled water from the coast (Mittelstaedt 1991). The CC system contains coastal upwelling, filaments and eddies (Johnson \& Stevens 2000). Actual upwelling is usually restricted to waters over the shelf and the upper slope within a narrow band of $20-30 \mathrm{~km}$. The source and nutrient load of the upwelled water alters between salty and nutrient-poor North Atlantic Central Water (NACW) and less saline, warmer and nutrient-rich South Atlantic Central Water (SACW). The frontal zone between NACW and SACW fluctuates between $21^{\circ} \mathrm{N}$ and $23^{\circ} \mathrm{N}$ (Barton \& Hughes 1982; Lange et al. 1998), undergoing spatial and temporal changes. The hydrography becomes complicated as both SACW and NACW may be upwelled and mixed laterally (Meunier et al. 2012). South of the area where the $\mathrm{CC}$ detaches, a cyclonic gyre of surface water exists between the offshore-moving $\mathrm{CC}$ waters and the coast throughout the year (between $10^{\circ} \mathrm{N}$ and $19^{\circ} \mathrm{N}$ ). This mesoscale cyclonic recirculation gyre changes its position and extension within the seasons, and is characterized by a large offshore extension of chlorophyll from February to May followed by an abrupt chlorophyll drop that propagates northward from May to June up close to the study region (Lathuilière et al. 2008).

The high biological productivity of this EBUS (Carr 2002) is caused by trade wind-driven coastal upwelling of nutrient-rich water that extends in a narrow band over $100 \mathrm{~km}$ along the coast. However, the productive band of high phytoplankton biomass is wider and extends $500 \mathrm{~km}$ offshore due to the influence of filaments developing and moving offshore by wind forcing, as present off Cape Blanc (van Camp et al. 1991; Gabric et al. 1993; Kostianoy \& Zatsepin 1996; Lange et al. 1998; Lathuilière et al. 2008; Meunier et al. 2012). These filaments of cold upwelled water have been shown to be important sources of offshore transport from the nutrient-rich coastal water to the more oligotrophic open oceans (Alvarez-Salgado et al. 2001, 2007). Within the phytoplankton responsible for the high pigment concentrations in these filaments coccolithophores play an important role (Fischer et al. 2007).

In general, the upwelling process is induced by the trade winds which vary in strength through the year, with stronger periods in spring, summer and autumn (Mittelstaedt 1991; van Camp et al.
1991; Barton 1998). During the study period (March 1989 and December 1991) the wind speed displayed minimum velocities during winter and autumn (January and November 1989) (Fig. 2a). In general, the prevailing wind direction shifted between the NE and NW with the NE direction persisting in (autumn) winter.

The temperature difference between the mooring location and an open ocean location at the same latitude but in the centre of the ocean $\left(40^{\circ} \mathrm{W}\right)$ was used to define a sea surface temperature anomaly as an indicator of upwelling or of upwelling filaments (Nykjær \& van Camp 1994). Speth et al. (1978) classified a difference of $-3 \mathrm{~K}$ (and lower) as indicative of upwelling. From this index (Fig. 2b) it appears that upwelling filaments extended to the study region in summer 1989 and 1991, whereas in summer 1990 the influence of those filaments was reduced. However, weak upwelling filaments influenced the site location from winter to summer 1990 (Fig. 2b).

\section{Material and methods}

The deployments of the sediment traps and the initial treatment of the collected samples are described in detail by Fischer et al. (1996). Cone-shaped multisampling sediment traps with 16-22 cups and $1.17 \mathrm{~m}^{2}$ (CB 2) or $0.5 \mathrm{~m}^{2}$ (CB 3, 4) collection area were deployed. This study investigated a total of 58 samples from three time-series traps moored at approximately $3500 \mathrm{~m}$ below the sea surface over three deployments (CB 2-4) with varying lengths and sampling intervals (see Table 1).

\section{Quantification of coccolith fluxes}

The coccolithophorid preparation generally followed the method of Andruleit (1996). Depending on the particle content of the samples a split of 1/640-1/6400 of the original was filtered on to polycarbonate membrane filters (Schleicher and SchuellTM $47 \mathrm{~mm}$ diameter, $0.45 \mu \mathrm{m}$ pore size). A piece of the filter was cut and mounted on a SEM stub. In an arbitrarily chosen transect coccoliths and coccospheres were counted until a total of at least 500 coccoliths was reached. Qualitative and quantitative analyses of the fluxes were performed using a Zeiss DSM 940A at $10 \mathrm{kV}$ accelerating voltage. Each coccolith was identified to the lowest taxonomic level possible. The taxonomic classification is based on Young et al. (2003) and Cros (2001, unpublished PhD thesis, University of Barcelona). Full taxonomic citations are given in Appendix A.

Fluxes of coccospheres were further converted into fluxes of coccoliths to consider the very small fluxes of coccospheres as well. Therefore, species-specific values of mean coccolith numbers per coccosphere were used as described in Boeckel \& Baumann (2008). Hence, all coccolith fluxes displayed are the sum of counted coccoliths and converted coccospheres. In addition, a ratio is introduced here that was used to identify variations in surface water conditions: this ratio (Index LPZ) is given as

$$
\text { Index LPZ }=\frac{\text { Flux of LPZ }}{\text { Flux of Emiliania huxleyi }+ \text { Flux of LPZ }} \text {, }
$$

with LPZ being the absolute fluxes of the lower photic zone species Florisphaera profunda, Algirosphaera spp. and Gladiolithus flabellatus.

\section{Statistical methods}

In order to assess the relationship between coccolith occurrences and known environmental variables, a statistical analysis was carried out using the multivariate statistical package CANOCO 4.54 (CANOnical Community Ordination: version 4.54) for Windows. Initially a Detrended Correspondence Analysis (DCA) was carried 


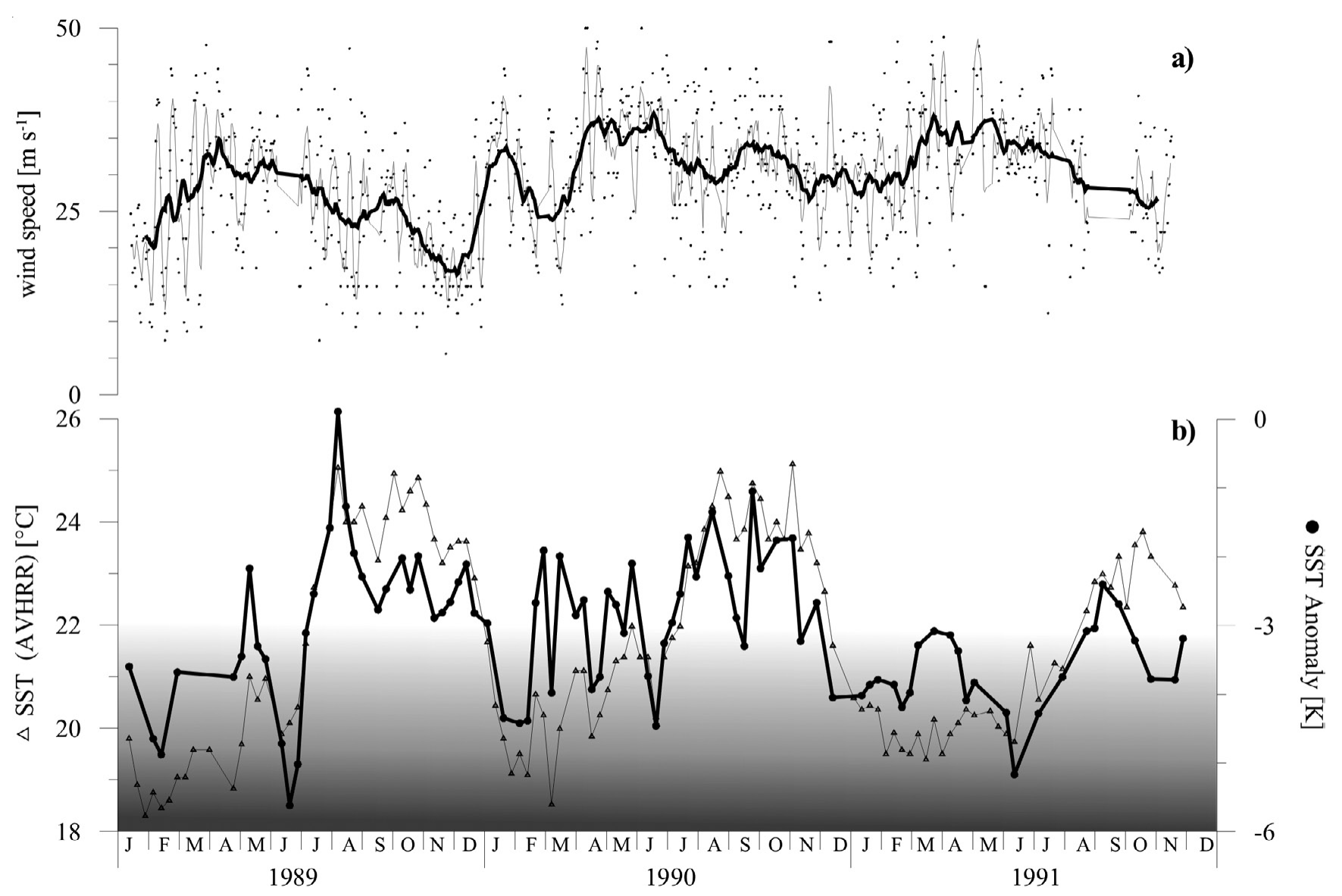

Fig. 2. (a) Wind speed measured at Nouadhibou airport, Mauritania (data from Ratmeyer pers. comm. 10/2012); fine line is 3-point moving average; thick line is function of polynomial. (b) Sea-surface temperature (SST, thin line with triangles) from mooring location (Advanced Very High Resolution Radiometer (AVHRR) data from http://oceanwatch.pfeg.noaa.gov/) and SST Anomaly (in bold and with dots) calculated as the difference in temperature between the mooring location and a mid-ocean $\left(40^{\circ} \mathrm{W}\right)$ location at the same latitude.

Table 1. Summary of Cape Blanc sediment trap details

\begin{tabular}{lcccccc}
\hline Mooring & Trap type (opening) & Position & Water depth $(\mathrm{m})$ & Trap depth $(\mathrm{m})$ & Sampling duration & Samples $\times$ days \\
\hline CB 2 & Mark VI $\left(1.17 \mathrm{~m}^{2}\right)$ & $21^{\circ} 08.7^{\prime} \mathrm{N} / 20^{\circ} 41.2^{\prime} \mathrm{W}$ & 4092 & 3502 & 15 March 1989-24 March 1990 & $22 \times 17$ \\
CB 3 & Kiel SMT 230 $\left(0.5 \mathrm{~m}^{2}\right)$ & $21^{\circ} 08.3^{\prime} \mathrm{N} / 20^{\circ} 40.3^{\prime} \mathrm{W}$ & 4094 & 3557 & 20 April 1990-8 April 1991 & $16 \times 21.5$ \\
CB4 & Kiel SMT 230 $\left(0.5 \mathrm{~m}^{2}\right)$ & $21^{\circ} 08.7^{\prime} \mathrm{N} / 20^{\circ} 41.2^{\prime} \mathrm{W}$ & 4108 & 3562 & 3 May 1991-19 November 1991 & $20 \times 10$ \\
\hline
\end{tabular}

out. This showed that the species response curves have a linear rather than a unimodal character. As a consequence, the linearbased multivariate ordination method of Redundancy Analysis (RDA) was applied using the entire dataset of absolute species fluxes (van Wijngaarden et al. 1995; Lepš \& Šmilauer 2003). With this method the direct relationship between an environmental variable and the species occurrence and relative abundance can be determined.

As environmental variables, nitrate at $20 \mathrm{~m}$ water depth (N20 data from the World Ocean Atlas - WOA), sea surface temperature (SST) from the Advanced Very High Resolution Radiometer (AVHRR) and lithogenic particles of the trapped samples (data from Fischer et al. 1996) were used.

The results of the RDA will be summarized in an ordination diagram in which the observed vectors represent the gradients of the environmental data and ordinates assemblages, i.e. samples, as points. The correlation coefficient between a species and an environmental factor as represented by the species RDA score corresponds to the cosine of the angle between the species line and that of the environmental variable. A positive score indicates that the species shows a linear increase in relationship to increasing environmental variable, a negative score indicates that the species abundance decreases when the environmental gradient value increases. The length of an arrow representing a known variable represents the importance of the variable in determining the species variation. Samples that plot close to the centre of the diagram are most likely not significantly affected by the tested environmental gradients. The relative abundance of species that plot at the positive or negative ends of an environmental arrow is strongly positively or negatively related to that environmental gradient, respectively (van Wijngaarden et al. 1995).

\section{Results}

The flux of coccoliths varied seasonally and inter-annually, with relatively lower numbers of coccoliths during (late) summer to autumn (see Fig. 3). The flux generally varied between about $500 \times 10^{7}$ liths $\mathrm{m}^{-2} \mathrm{~d}^{-1}$ and less than $10 \times 10^{7}$ liths $^{-2} \mathrm{~d}^{-1}$, with an average coccolith flux of $244 \times 10^{7} \mathrm{~m}^{-2} \mathrm{~d}^{-1}$. Nevertheless, a single peak of $1770 \times 10^{7}$ liths $\mathrm{m}^{-2} \mathrm{~d}^{-1}$ occurring in January/February 1991 stands out from the general trend. Two sample gaps, both of a month's time, slightly bias the general pattern.

The assemblage was diverse and included six species found in both their holo- and heterococcolith-bearing stages, a further 74 heterococcolith-bearing species and seven holococcolith-bearing 


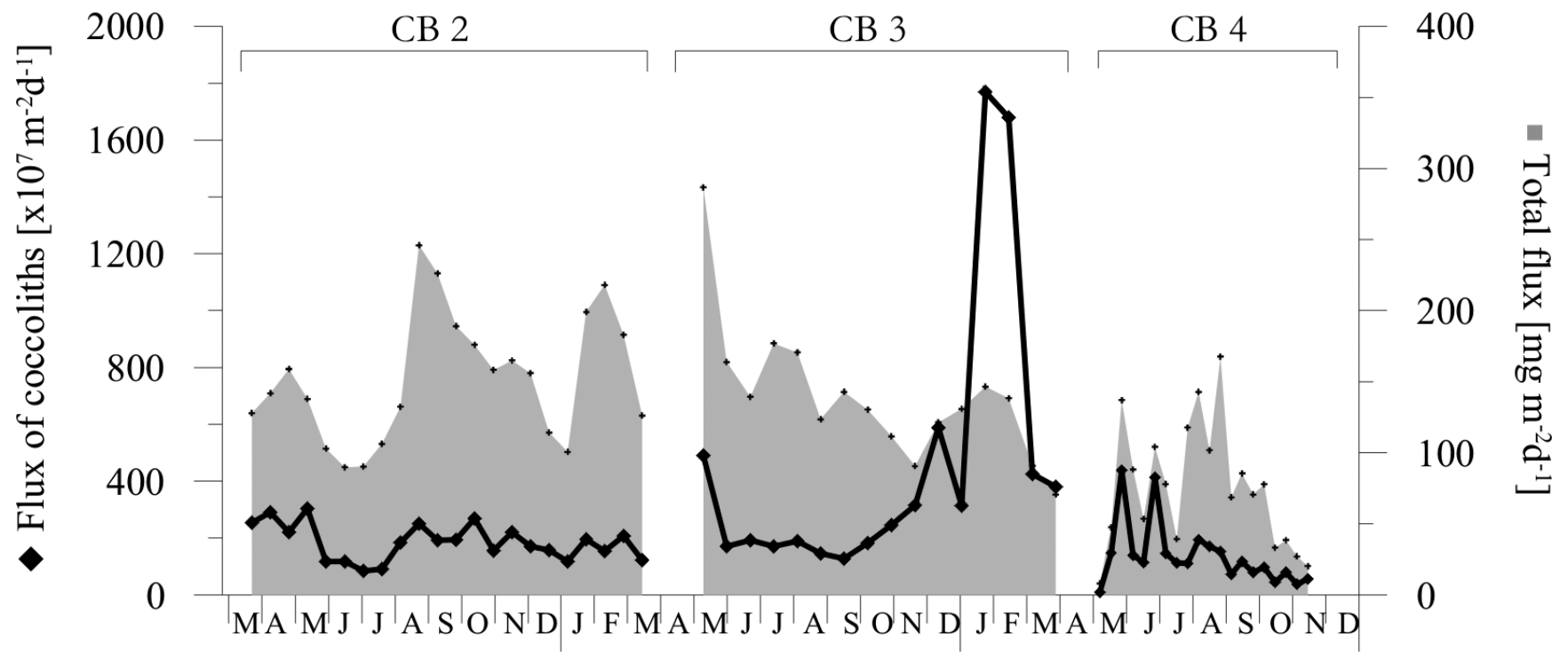

1989

1990

1991

Fig. 3. Total Flux (bold, black diamonds) and total flux (grey shaded area) between 1989 and 1991 off Cape Blanc (data of total flux from Fischer et al. 1996).

species. All counted specimens were excellently preserved. A summary of species that were common and frequently found is given in Table 2. For statistical analysis the dataset was reduced to those species that occurred at least once with a relative abundance of at least $5 \%$ or were present in more than $95 \%$ of the samples. Also, species of the genus Calcidiscus were considered because in general they significantly contribute to calcium carbonate fluxes due to their large specific carbonate mass. In Table 2, Syracosphaera spp. includes all small-sized taxa of the genus, which could not be unambiguously identified. In the summary of Figures 4 and 5, species such as Syracosphaera anthos, S. pulchra, S. tumularis and the other 18 species of Syracosphaera were all included as Syracosphaera spp..

\section{Inter-annual variability in coccolithophore fluxes}

The dominant taxa in terms of absolute fluxes are Emiliania huxleyi, Florisphaera profunda and Gephyrocapsa spp. (Fig. 4). In addition, Ophiaster spp. and Acanthoica spp. added significantly to the fluxes in January/February 1991. The assemblage over the entire studied interval was dominated by E. huxleyi with an average contribution of $34 \%$, varying from a minimum of $17 \%$ in December 1990 to a maximum of 56\% in June 1991. During the minimum in E. huxleyi, in December 1990, the maximum relative abundances of $F$. profunda and Gladiolithus flabellatus were observed. Shortly after (January to March), Gephyrocapsa spp., G. flabellatus, F. profunda, Umbellosphaera spp., Umbilicosphaera spp., Calcidiscus leptoporus ssp. quadriperforatus and C. leptoporus showed minimum relative abundances. At the same time, the relative (and absolute) abundances of Ophiaster spp. and Calciopappus spp. increased significantly, reaching maxima of $28 \%$ and $7 \%$, respectively. During the remaining time, Ophiaster spp. and Calciopappus spp. were only minor components of the assemblage (c. $4 \%,<1 \%$ respectively) (Fig. 5).

Additionally, in December 1990 the flux of Umbellosphaera tenuis increased, followed by a rapid decrease. Florisphaera profunda also increased in December and slightly decreased in January/February 1991; however, the high fluxes persisted. In January to February (1991) fluxes of E. huxleyi, Ophiaster spp., Acanthoica spp. and Algirosphaera spp. increased significantly as well as the fluxes of Calciosolenia spp., Umbilicosphaera hulburtiana and Calcidiscus leptoporus. A considerable increase in fluxes of Gephyrocapsa ericsonii and holococcolithophores occurred in February 1991 as well (Fig. 4).

In summary the species composition of the coccolith fluxes shows two distinct intervals. The 'normal' assemblage is characterized by fluctuating coccolith fluxes and is present from March 1989 until winter 1990/1991 and again from April 1991 to October 1991. A dramatic increase in coccolith flux together with an associated change in species composition shows a distinct 'event' in the winter months of 1990/1991 (Fig. 4).

\section{Statistical results}

The relationship between the coccolithophore species composition and underlying environmental gradient(s) is best described by a linear response. The lengths of gradient are 1.277, 0.999, 0.919 and 0.483 . Covariance of the environmental parameters used (SST by AVHHR, flux of lithogenic particles of the studied samples and N20 by WOA) was excluded. A Monte Carlo test indicated a lack of covariance of the applied environmental parameters. In Table 3 the results of the RDA are summarized, showing that even the first ordination axis (SST) is quite low in eigenvalue (0.144). It explains only $14.4 \%$ of the species variance in the total sample set, suggesting that other underlying environmental factors are driving the observed assemblage variations. Nevertheless, within the tested environmental parameters SST counts for $97 \%$ of the environment-species relationship. The variability in flux of lithogenic particles as the second axis reveals a certain relationship to the variability of the coccolithophore fluxes $(2.6 \%)$, whereas the relevance of nitrate (at $20 \mathrm{~m})$ is very low $(0.4 \%)$.

\section{Discussion}

Time-series sediment traps provide high resolution and continuous data on the coccolithophore export production, which should represent an integrated signal of coccolithophore production in the overlying surface waters. With respect to both absolute fluxes and the species composition, the coccolithophore assemblage off Cape Blanc reveals remarkable inter-annual variations. As a result, we defined a pattern of species assemblage as 'normal' condition and observed an 'event' of significant changes in species composition 
Table 2. Summary of identified taxa in respect of frequency and abundance and complete list of holococcolith-bearing species

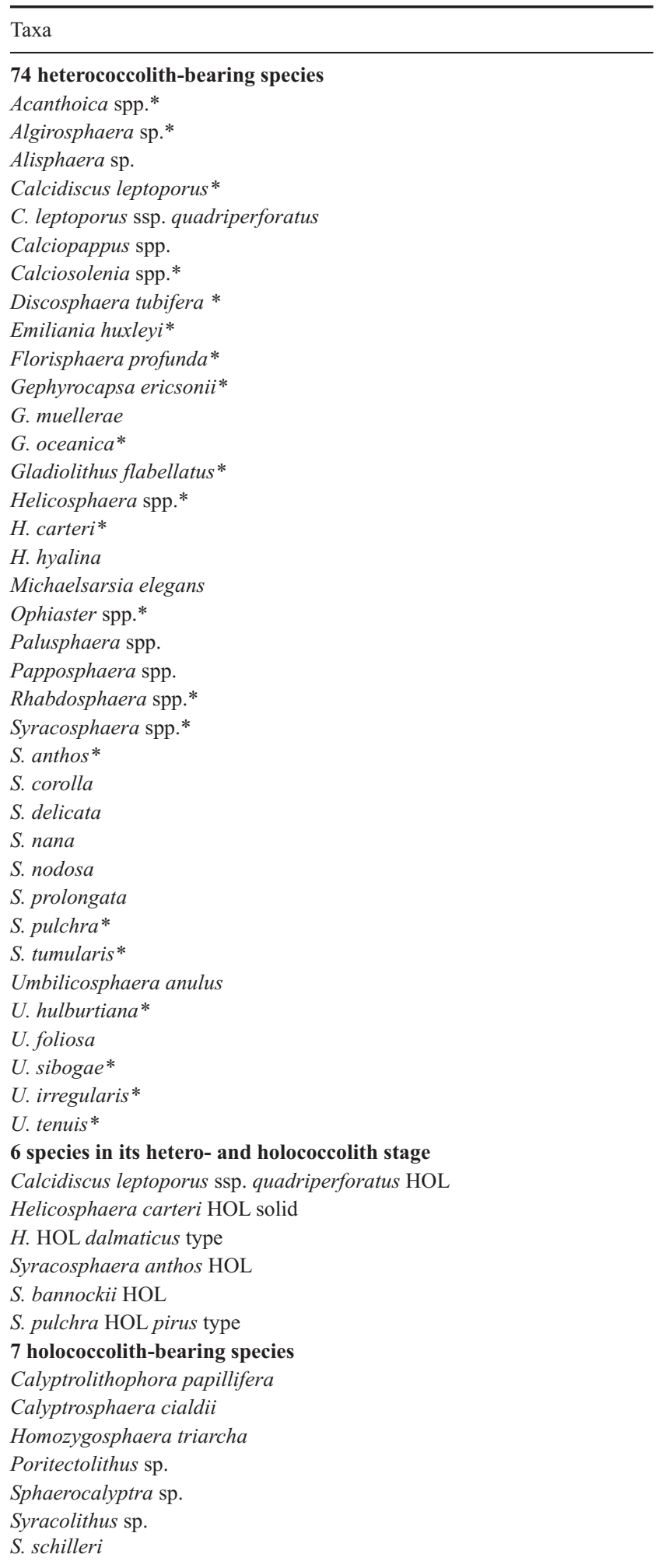

*indicates species found in $>95 \%$ of the samples; other species found at least once with a relative contribution of $5 \%$.

For complete taxonomic list see Appendix A.

and fluxes. As a consequence, the study period can be divided into three periods in which distinct species compositions, fluxes and environmental conditions were present: from spring 1989 to autumn 1990 ('normal'), winter 1990/1991 ('event'), and spring to autumn 1991 ('normal'). The initial 'normal' assemblage had a rather uniform overall species composition despite significant intra-seasonal changes in coccolith flux. This was replaced by an event assemblage and high fluxes, before returning to a normal assemblage, with significantly reduced fluxes, but similar species composition as the first interval.

\section{Coccolithophore fluxes and variations during seasons of 'normal' conditions}

The assemblage during the 'normal' period was characterized by the fluxes of E. huxleyi, F. profunda, G. flabellatus, G. oceanica and G. ericsonii. Variations in both abundances and fluxes within this assemblage point to the occurrence of varying surface waters most probably influenced by offshore meandering filaments. Throughout this period E. huxleyi was the dominant taxa, however, with varying fluxes through the years and the seasons. This corresponds with the characteristic of E. huxleyi as a cosmopolitan species that flourishes in a wide range of environmental conditions but tends to favour rather mature waters (Townsend et al. 1994). Emiliania huxleyi, living in surface water, can increase its production in response to improving environmental conditions, for example, increase in nutrients by highly increased fluxes. Therefore, the Index LPZ (ratio of LPZ flora to E. huxleyi, F. profunda, G. flabellatus and Algirosphaera spp.) gives more detailed information for the existing environmental conditions (Fig. 6). The LPZ species live in deeper water below the nutricline (Okada \& Honjo 1973; Probert et al. 2007; Boeckel \& Baumann 2008) and are, therefore, adapted to lower light conditions. From spring 1989 to summer 1990 there are only slight fluctuations in the Index LPZ (Fig. 6). This suggests that the influence of filaments was of low intensity and short duration, if present at all, during this period (Fig. 6). As a result the region may be slightly reduced in nutrient concentration, thus favouring species living close to the nutricline. Species of Umbellosphaera and Discosphaera, indicators of oligotrophic warm water of the upper photic zone (Jordan \& Winter 2000; Cortes et al. 2001), recorded relatively high relative abundances only during 'normal' conditions and, thus, inferring their preferences for oligotrophic conditions caused by increased SST, stratification and lack of nutrient supply due to weak wind velocities. Furthermore, the reduced wind velocities may have supported stratification of the water column and so promoted the occurrence of $F$. profunda and species with similar habitat. In contrast, $E$. huxleyi may be at a disadvantage during that time (autumn to winter 1990). However, it outcompetes the assemblage of lower photic zone species by flourishing significantly due to the sudden and long-lasting upwelling influence that started in winter 1990/1991 and lasted to summer 1991.

In addition to the species that numerically dominate fluxes, other species such as Gephyrocapsa muellerae, C. leptoporus (small) and Umbilicosphaera foliosa are of interest, due to their characteristic environmental preferences and their inter-annual flux pattern. Gephyrocapsa muellerae and the small morphotype of $C$. leptoporus, which are species associated with nutrientenriched waters (Boeckel \& Baumann 2008), are present in significant abundances from August 1989 to March 1990. This indicates a period of nutrient enrichment probably associated with cooler surface-water temperatures as suggested by the coccolith species composition. In the subsequent months, $U$. foliosa, which prefers (more) oligotrophic conditions (Boeckel \& Baumann 2008), slightly increases, whereas G. muellerae disappears and C. leptoporus (small) is significantly reduced. These changes may indicate that upwelling was less intense during this interval or may document that the area was influenced by reduced numbers of filaments passing the trap location.

One explanation can be the mechanism of meandering filaments of upwelled coastal waters off Cape Blanc. These filaments may persist for weeks (e.g. Pellegrí et al. 2005; Alvarez-Salgado et al. 2007). They can also break apart abruptly and may create small 


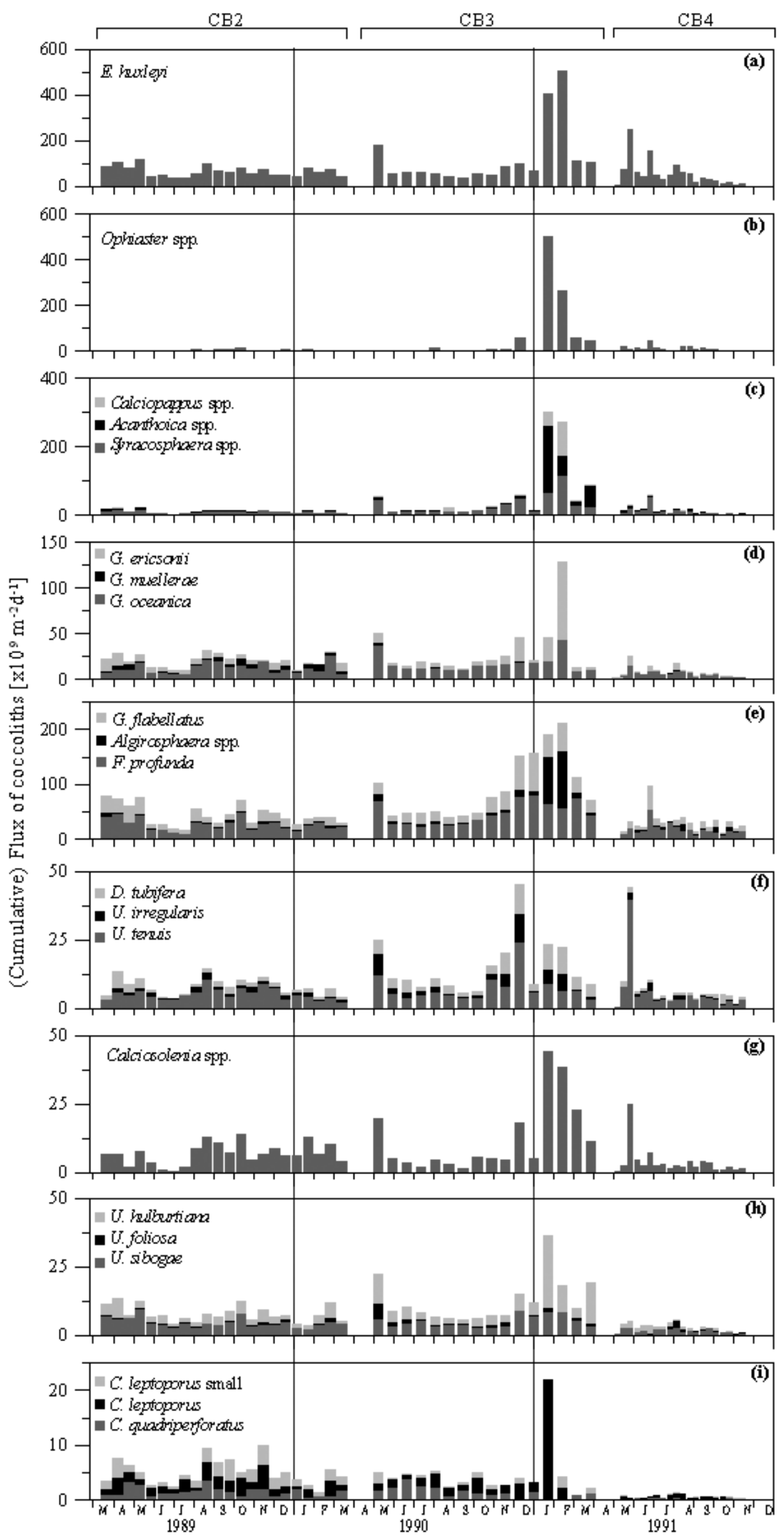

Fig. 4. Absolute fluxes of significant coccolithophore species off NW Africa (Cape Blanc) during March 1989 to November 1991. 


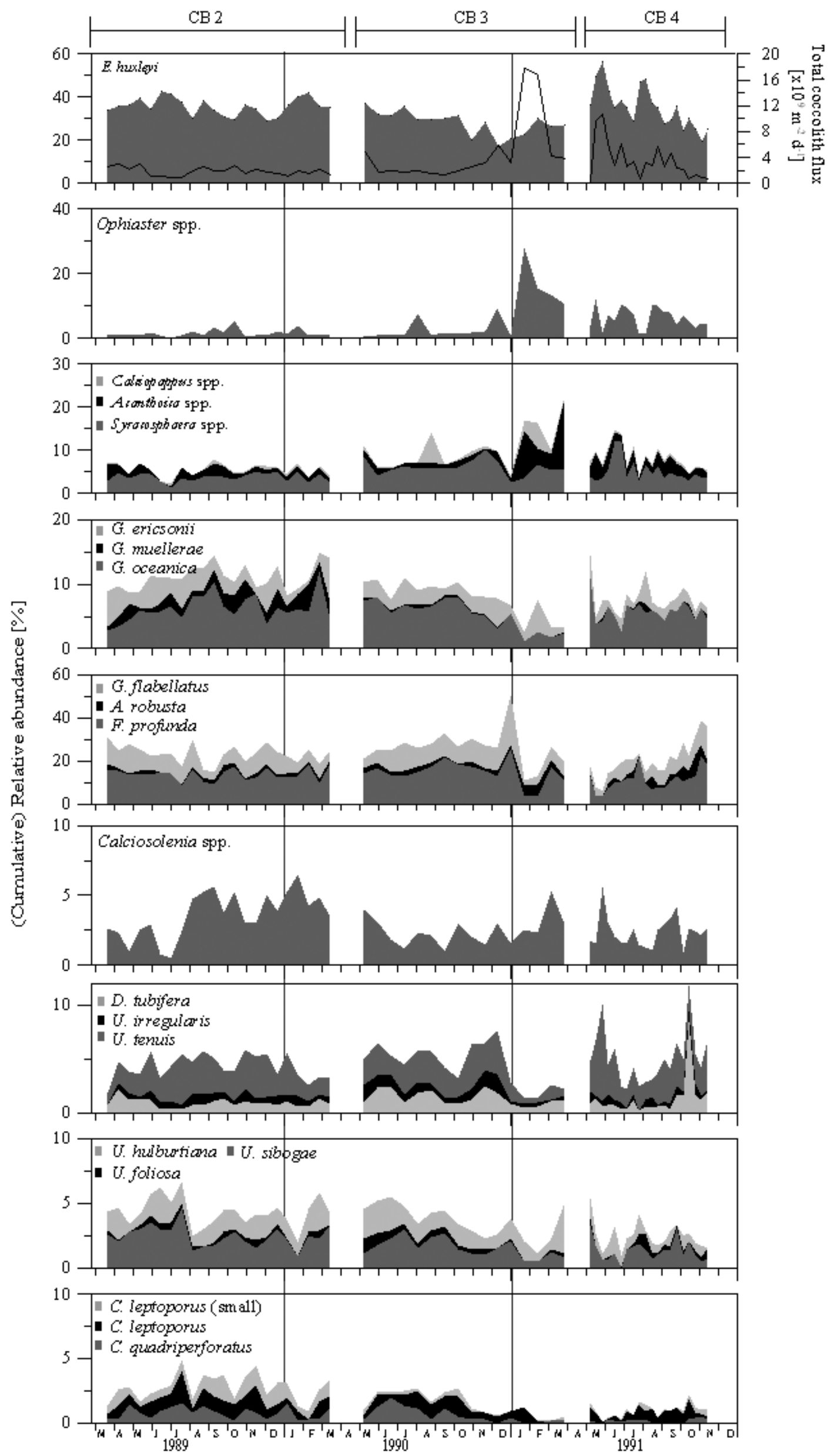

Fig. 5. Relative abundance of common species of coccolithophores. 
Table 3. Results of redundancy analysis (RDA) with the environmental parameters (1) SST (AVHRR), (2) flux of lithogenic particles of the samples, (3) nitrate concentration at $20 \mathrm{~m}$ depth (WOA) and (4) further unknown variables

\begin{tabular}{lcccc}
\hline Axes & 1 & 2 & 3 & 4 \\
\hline Eigenvalues & 0.144 & 0.004 & 0.001 & 0.708 \\
$\begin{array}{l}\text { Species-environment correlations } \\
\text { Cumulative percentage variance of }\end{array}$ & 0.412 & 0.220 & 0.262 & 0.000 \\
$\begin{array}{l}\text { species data } \\
\text { of species-environment relation }\end{array}$ & 97.0 & 14.8 & 14.8 & 85.7 \\
\hline
\end{tabular}

eddies of surface water. The changes in species composition of coccolithophores may indicate these different water conditions starting with enriched waters, possible influenced by a (small surface water) eddy and changing to more oligotrophic conditions. As a result the 'normal' condition observed off Cape Blanc reveals a highly dynamic system with coccolithophore assemblages indicating these specific dynamic small-scale oceanographic changes.

\section{Pulse-like sedimentation event off Cape Blanc}

The total coccolith flux increased significantly during winter 1990/1991 (Fig. 3) and complete and very well-preserved coccospheres, even of holococcolithophores and Ophiaster spp., were observed (Pl. 1). The flux increase is partially due to an increase in E. huxleyi but is also due to marked increases in species of the genera Ophiaster, Acanthoica, Calciosolenia, Calciopappus and Syracosphaera, as well as of holococcolithophore species. LPZ species also show slightly enhanced flux rates. The occurrence of a much higher flux than observed during the remaining study period might be the result of higher production, less dissolution, less dilution and/or faster settling. Coccolith concentration can act as an indicator for these processes. The coccolith concentration, expressed as the ratio of total coccolith flux versus total flux, is affected by production, dilution of the collected material, as well as carbonate dissolution. It shows an increase from autumn 1990 to winter 1991, whereas a rather constant ratio was present during the remaining time (Fig. 7). The increase points to an increase in relative contribution of coccolithophores to the total flux. As stated before, dissolution as a reason can be excluded due to the consistent presence of the well-preserved fragile species and even the presence of whole coccospheres. The excellent preservation of species with minute and fragile coccoliths, i.e. many small Syracosphaera species, Ophiaster spp. and holococcolithophores, indicates a fast settling velocity and so a short residence in the water column. This finding is in good agreement with previous observations on the same sediment traps. Müller \& Fischer (2001) concluded from their comparative study of alkenone-based reconstructions of SST an increased settling velocity by a factor of four during the deployment of the sediment trap CB 2 to CB4 (1989-91). While a rather uniform sinking rate of about $63 \mathrm{~m} \mathrm{~d}^{-1}$ was estimated for the time interval till October 1990, the particle sinking rates have been calculated to have been close to or even greater than $280 \mathrm{~m} \mathrm{~d}^{-1}$ during the time of the 'pulse-like event'. More recently Fischer \& Karakas (2009) observed fast sinking, densely packed zooplankton faecal pellets, which transport high amounts of organic carbon associated with coccoliths to the deep ocean despite rather low production. They described particle-sinking rates reaching almost $570 \mathrm{~m} \mathrm{~d}^{-1}$ during a summer coccolithophorid bloom in the study area.

Coccoliths may also have been associated with the processes involved in scavenging of small particles within the water column (Nowald et al. 2006; Ziveri et al. 2007). A trigger mechanism in the study region is the input of wind-transported dust that is coupled with the input of high-density lithogenic material (Fischer et al. 1996). The terrigenous grains collide with the phytodetritus in the water column which leads to higher sinking rates. Due to their large abundance the small coccolithophores are preferentially scavenged during sinking. During the time interval of heavily increased coccolith fluxes, high lithogenic fluxes were observed in the CB traps (Ratmeyer et al. 1999). Nowald et al. (2006) describe such events as 'pulse-like sedimentation events', which may be triggered by phytoplankton blooms.

Species of the genus Ophiaster flourish in mid-photic to lower photic waters (Jordan \& Winter 2000; Cros 2001 unpublished PhD thesis, University of Barcelona); however, in the Pacific the genus is included in the upper photic assemblage (Hagino et al. 2000). The diverse genus Syracosphaera includes species living in the upper photic zone, for example, S. pulchra and $S$. halldallii and in the middle photic zone, for example, S. molischii (Hagino et al. 2000; Cros 2001 unpublished PhD thesis, University of Barcelona; Haidar \& Thierstein 2001); however, regional and seasonal variations do exist. Due to the shift in species composition, the elevated coccolith concentration and the very good preservation of the coccoliths, we assume that an increase in occurrence in species of the upper and middle photic zone combined with a reduced lower

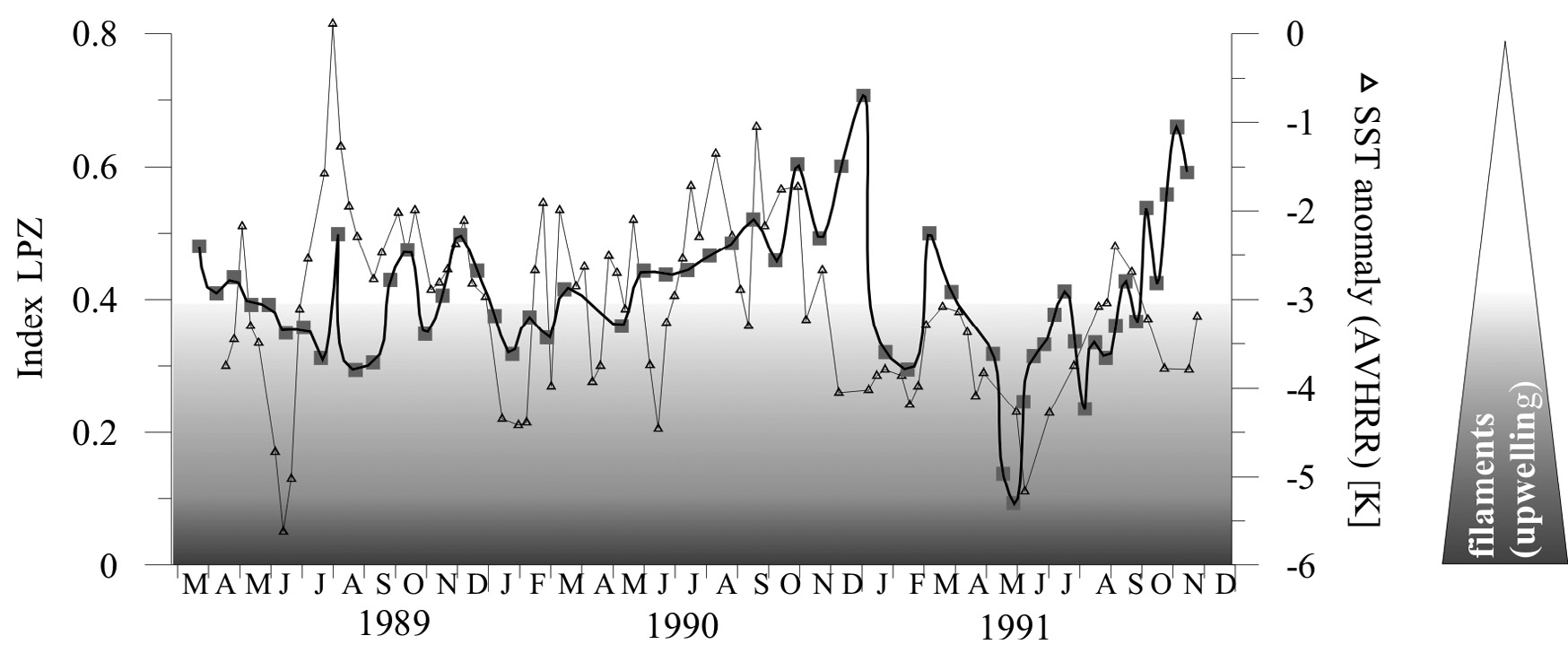

Fig. 6. Ratio of LPZ species (F. profunda, G. flabellatus and Algirosphaera spp.) versus sum of LPZ species and E. huxleyi (solid black line with grey squares) in comparison with the SST anomaly. 


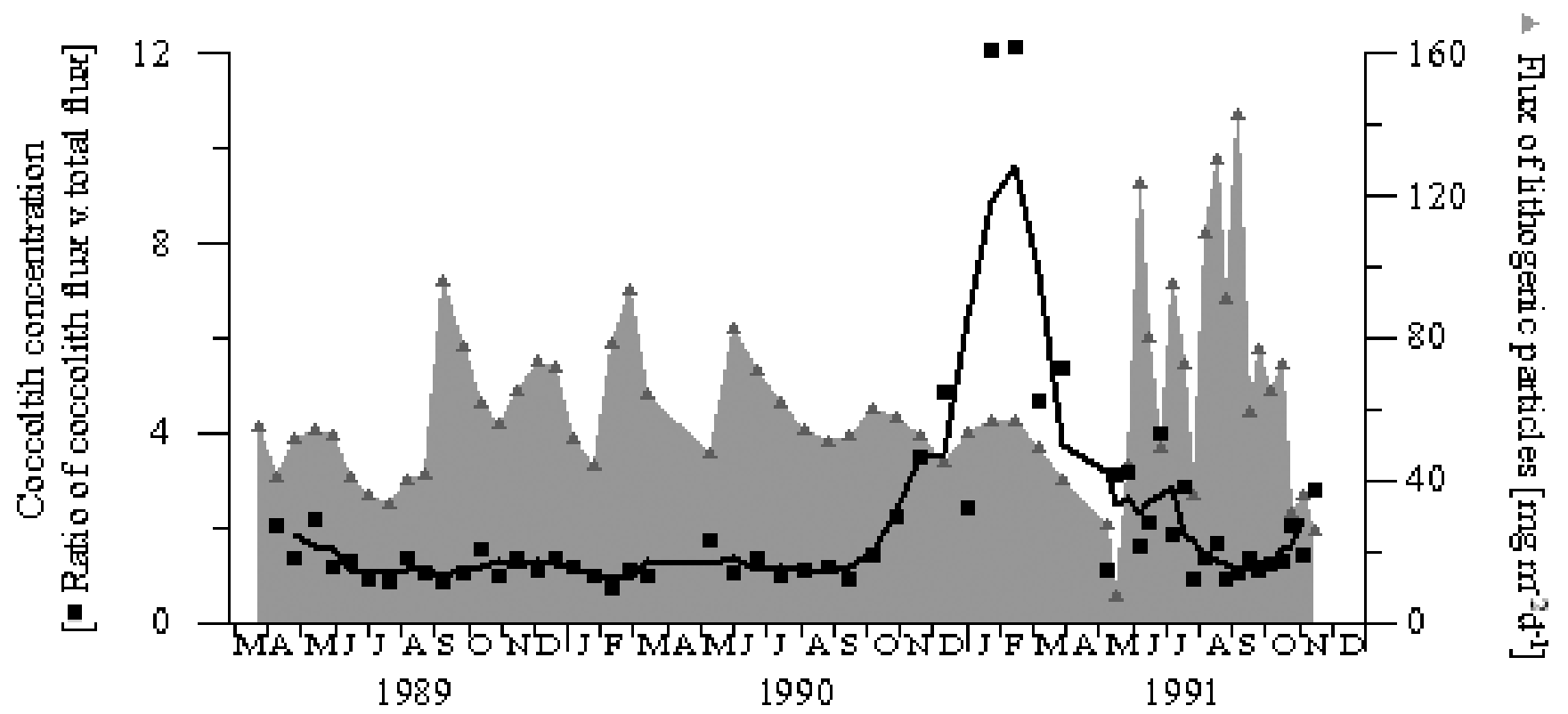

Fig. 7. Coccolith concentration (coccolith flux/total flux according to Beaufort \& Heussner (1999); solid black line is the 3-point-running average) in comparison to the flux of lithogenic particles (data from Fischer et al. 1996).

photic zone assemblage took place accompanied by a fast settling process during times of more oligotrophic conditions.

\section{Environmental parameters of influence during the seasons}

In this locality, off Cape Blanc, the coccolith fluxes appear to show more short-term variability and less pronounced seasonality than in other sediment trap studies (Broerse et al. 2000; Haidar \& Thierstein 2001; Triantaphyllou et al. 2005; Andruleit 2007). In order to determine the underlying factors that influence the studied coccolithophore fluxes, environmental parameters (SST, nitrate at $20 \mathrm{~m}$ depth and flux of lithogenic particles of the same samples) were related to

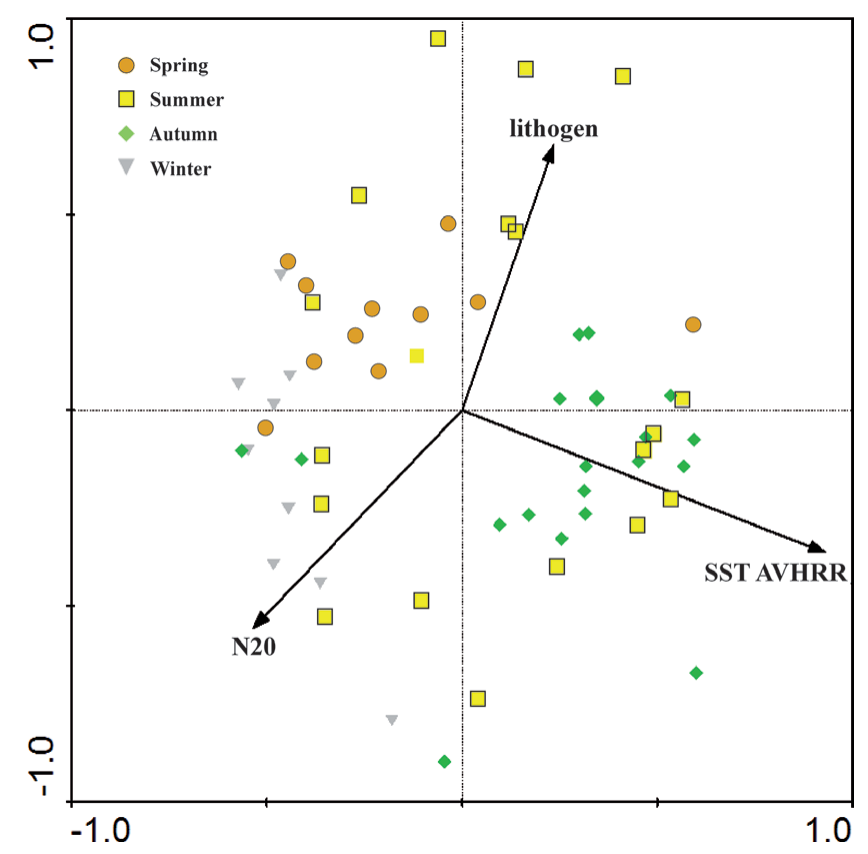

Fig. 8. Ordination biplot with the samples and environmental variables based on RDA: The environmental variables are N20 (nitrate at $20 \mathrm{~m}$ depth, data from WOA), SST of the mooring station (dataset from AVHRR) and lithogenic particle flux of the trap samples (Fischer et al. 1996). the total abundance of the identified species. The results show that of the tested environmental parameters, SST still has the greatest influence on the species-environment relationship. We assume that great changes in SST result in changes in the status of stratification of the water column, either building up the stratification or breaking it down. Both states directly influence the exchange of deeper water to the surface either by reducing or by increasing it. Additionally, off Cape Blanc changes in SST indicate the altering influence of the coastal upwelling filaments, either as a consequence of relaxation or increase of the coastal upwelling process (Giraudeau et al. 1993; Giraudeau \& Bailey 1995). As a result, the nutrient content of the surface water may vary significantly during times of drastic SST changes. The intense and highly variable jets, filaments and eddies in the studied area as seen in satellite images may also give an impression of the varying regional nutrient load and primary productivity of the surface water (van Camp et al. 1991; Kostianoy \& Zatsepin 1996). So, a turbulent mixing process between nutrient-rich coastal and nutrient-poor offshore waters occurs (Marchesiello et al. 2004).

The biplot in Figure 8 reveals more detailed information on the seasons. In autumn, the variability of the coccolithophore assemblage reveals a stronger correlation to SST than in the other seasons. In spring the variance in coccolithophore assemblage seems to correspond more with the fluxes of lithogenic particles. The lithogenic particles can be interpreted as indicative of additional nutrient input by wind. Recurring dust blown off the Mauritania coast is well known (e.g. Ohde \& Siegel 2010). The correlation of the spring samples with the nitrate content of the water may support this. A potential error might lie in the use of the WOA dataset. These data might not represent the actual hydrographic situation at the specific trapping time within this highly dynamic area, but since the trap assemblages represent up to three weeks much small-scale patchiness should be averaged out. In summer the situation seems more complex. Nutrients and SST have a certain influence on the assemblage variance; however, the results also suggest that further environmental factors may play a more important role.

\section{Comparison with other sediment traps in the Atlantic}

The coccolithophorid flux records may be altered by grazing by zooplanktonic organisms, dissolution of the tiny and fragile species 

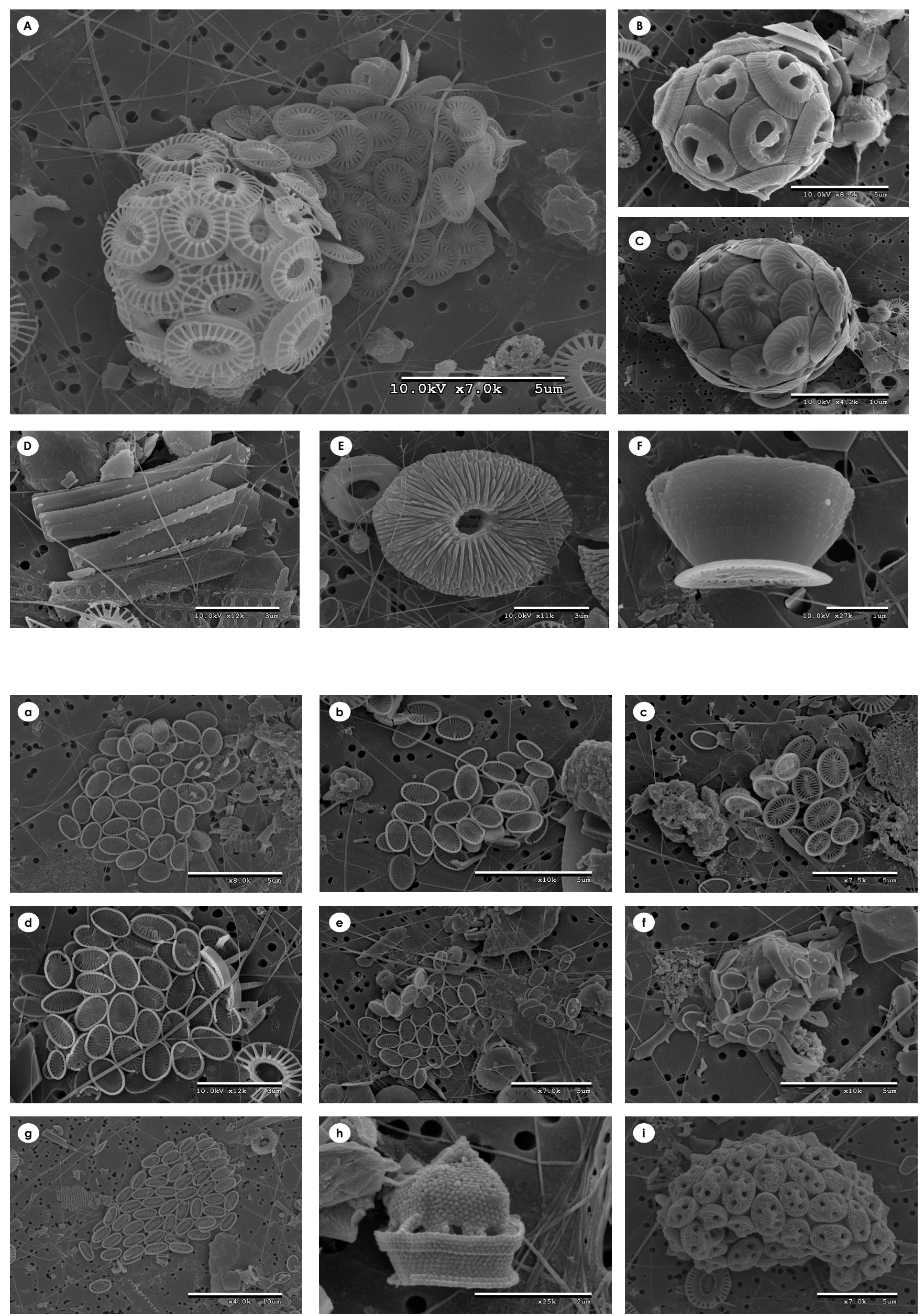

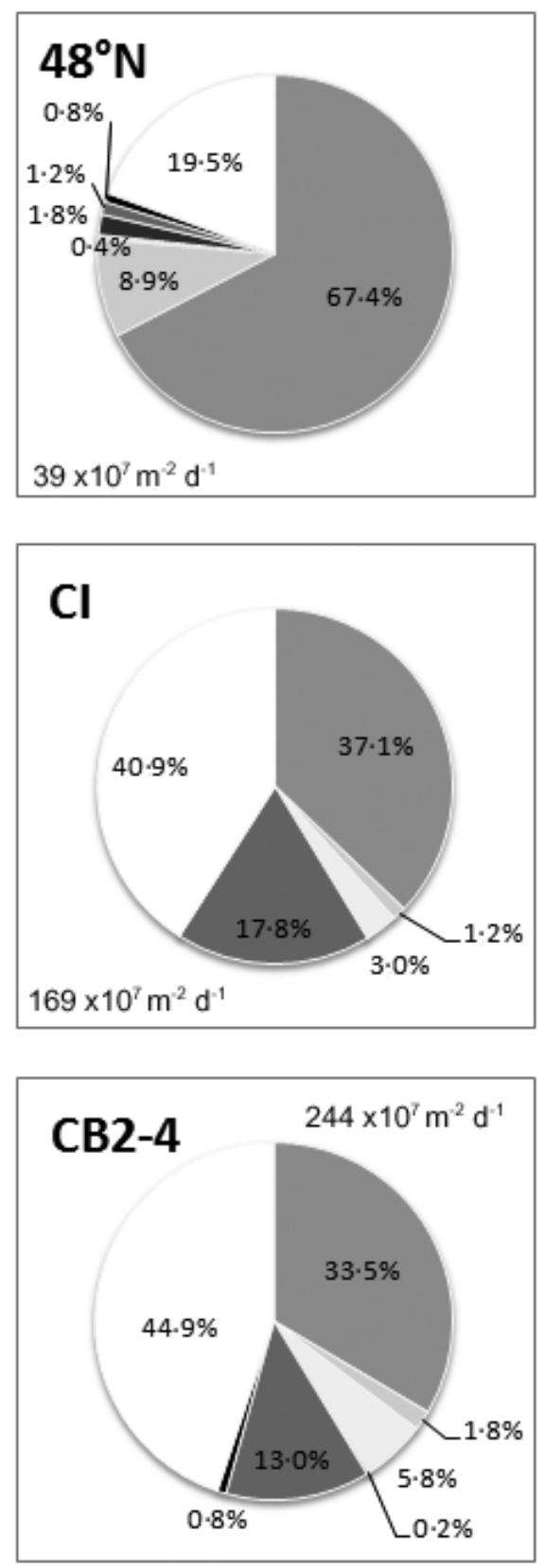
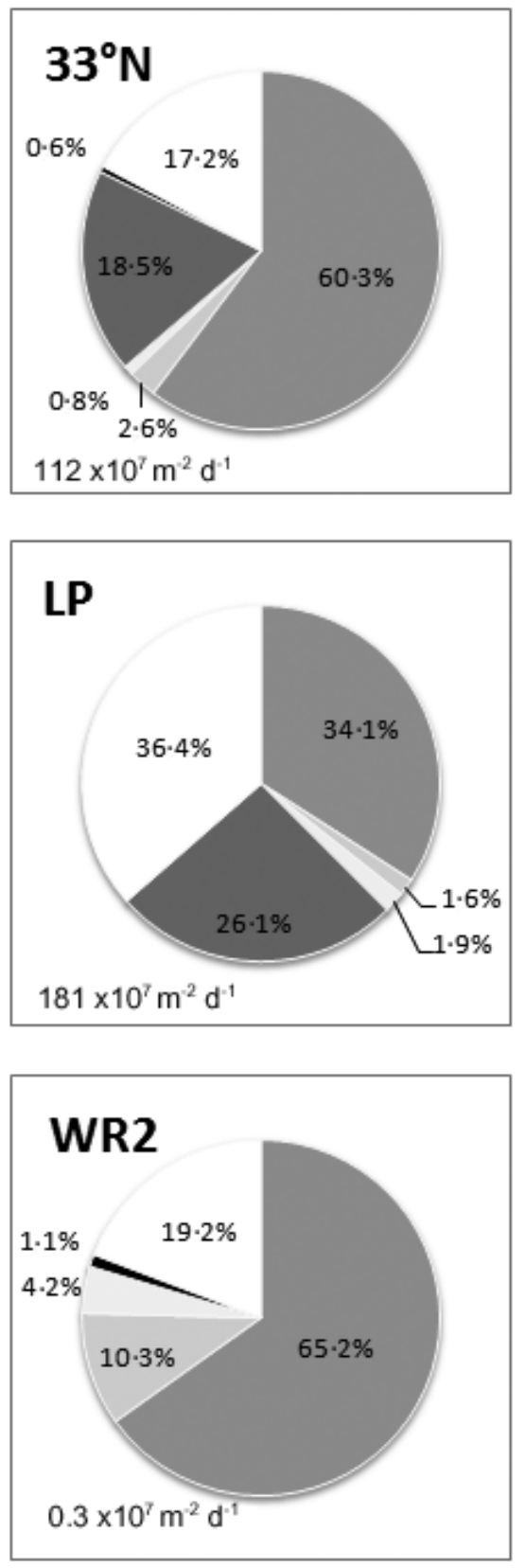
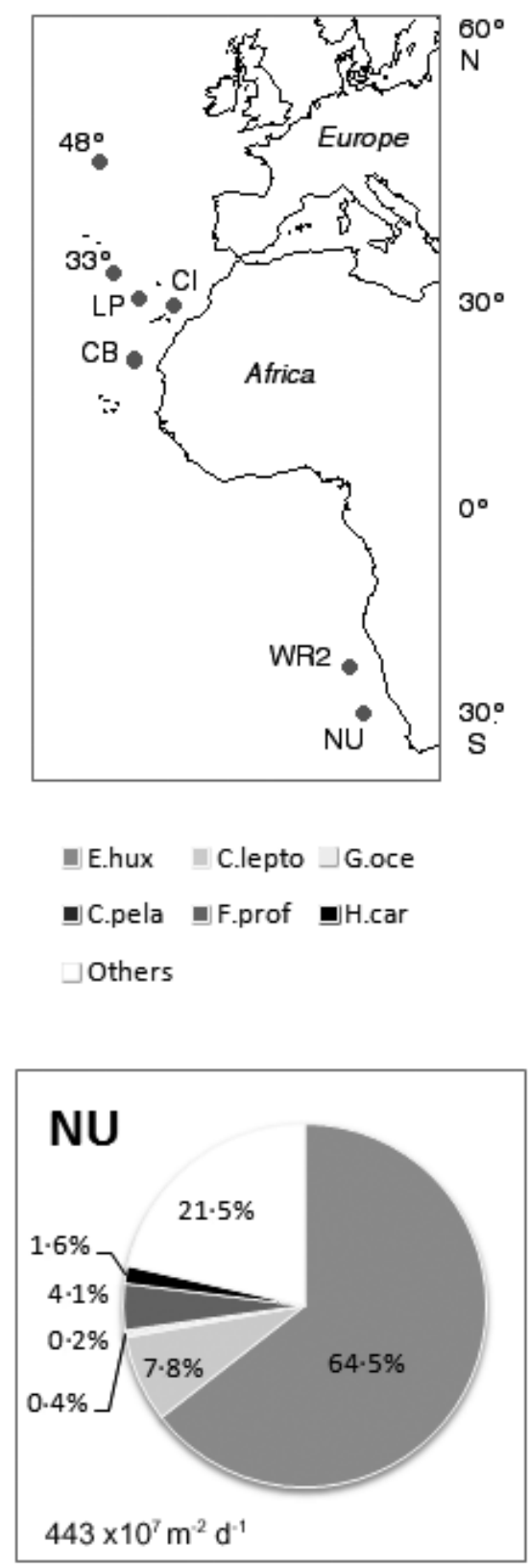

Fig. 9. Mean composition of the coccolithophore assemblages and average coccolith fluxes of selected sediment traps in the Atlantic Ocean (data of CB2-4 from this study, of $48^{\circ}$ and $33^{\circ} \mathrm{N}$ from Broerse et al. 2000; of CI and LP from Sprengel et al. 2000, of WR2 and NU from Romero et al. 2002). E. hux, Emiliania huxleyi; C. lepto, Calcidiscus leptoporus; G. oce, Gephyrocapsa oceanica; C. pela, Coccolithus pelagicus; F. prof., Florisphaera profunda; H. car, Helicosphaera carteri. The species are always in the same order (clockwise) arranged (corresponding to the key first row from left to right and then second row from left to right) - as long as they were present.

and lateral transport of material. None the less, reasonably coherent inferences of the mean coccolithophore production can be drawn on the basis of available sediment trap from different areas of the Atlantic.

Generally, the observed mean flux of $244 \times 10^{7}$ coccoliths $\mathrm{m}^{-2} \mathrm{~d}^{-1}$ off Cape Blanc (CB2-4) is well within the range of previously published data of this region (Köbrich \& Baumann 2009) and is also comparable to the Namibian upwelling off SW Africa where a mean flux of $443 \times 10^{7}$ coccoliths $\mathrm{m}^{-2} \mathrm{~d}^{-1}$ was recorded (Romero et al. 2002). Furthermore, all of the assemblages are characterized by a high coccolithophore diversity of more than 60 species. Only the Walvis Ridge (WR2) station in the northern Namibian upwelling shows a drastic reduction in average flux $\left(<1 \times 10^{7} \mathrm{coc}-\right.$ coliths $\mathrm{m}^{-2} \mathrm{~d}^{-1}$ ), which might be the result of a less efficient trap. The high velocity of the current above the WR2 mooring in a rather low water depth of $600 \mathrm{~m}$ may have had a pronounced influence on the flux. However, both a relatively high coccolithophore diversity of 40 species and a relative composition of the

Explanation of Plate 1. figs A-F. Coccolithophores found in sediment trap samples off Cape Blanc (CB2-4): A, Emiliania huxleyi, Acanthoica quattrospina; B, Gephyrocapsa oceanica; C, Calcidiscus leptoporus; D, Gladiolithus flabellatus; E, Umbellosphaera tenuis; F, Algirosphaera robusta. figs a-i. Coccolithophore species with small-sized coccoliths found especially during the 'pulse-like sediment event': a, b, Ophiaster spp.; c, Syracosphaera nodosa; d, Ophiaster sp.; e, Ophiaster formosus; f, Ophiaster hydroideus; $\mathbf{g}$, Michaelsarsia adriaticus; h, Syracosphaera pulchra HOL pirus type; i, Helicosphaera HOL dalmaticus type. 
coccolithophore assemblage similar to NU2 could be identified (Fig. 9). The assemblage composition of the SW African upwelling is, however, conspicuously different from that of NW Africa. Off SW Africa, E. huxleyi overwhelmingly dominated the mean coccolith flux, whereas the lower photic zone species $F$. profunda is almost absent. At NU2, a subordinate contribution of $C$. leptoporus was related to moderate productivity waters (Romero et al. 2002). In addition, the fluxes were added to by a relatively high proportion of diatoms, which certainly compete with coccolithophores for nutrients, and show a bimodal seasonality with major peaks in austral summer and winter, and moderate to low export in austral autumn and spring. In contrast, E. huxleyi built a prominent but less dominant proportion of the assemblage off NW Africa, where $F$. profunda was commonly present. A high proportion of other species, such as the fragile Ophiaster spp., Calciosolenia spp., Calciopappus spp. and Syracosphaera spp., but also Gephyrocapsa spp., were numerically more important than off SW Africa. The changes in total coccolithophore fluxes and species composition can be related to a predominant influence of upwelling-induced eddies replenishing the upper photic zone with nutrients, and a subordinate inflow of warm, oligotrophic waters from the south during times of decreased upwelling.

Surprisingly, the observed mean coccolith fluxes in the more oligotrophic sites of the temperate North Atlantic and the Canary Islands are also rather similar to those off Cape Blanc. The fluxes of coccolithophores at LP, CI and NABE $33^{\circ} \mathrm{N}$ are in the order of 110-180 coccoliths $\mathrm{m}^{-2} \mathrm{~d}^{-1}$, and are also characterized by a high coccolithophore diversity of more than 50 identified species per site. At all these sites, the high mean coccolith flux is primarily related to the deep mixing of the water column during late winter/early spring and the replenishment of the photic zone with nutrients (Sprengel et al. 2000). Thus, extremely high coccolith fluxes occurred mainly in spring, whereas otherwise only low fluxes were recorded (Broerse et al. 2000 Sprengel et al. 2000, 2002). All stations, but in particular NABE $33^{\circ} \mathrm{N}$, are dominated by E. huxleyi, but are also characterized by a relatively high portion (up to $28 \%$ ) of $F$. profunda. Variation in the species composition was low, reflecting the same seasonal flux patterns of the different species during the sampling periods.

At the northernmost station NABE 48 , a flux of only $39 \times 10^{7}$ coccoliths $\mathrm{m}^{-2} \mathrm{~d}^{-1}$ was reported and the coccolithophore diversity was also significantly lower compared to $33^{\circ} \mathrm{N}$. Broerse et al. (2000) discussed, as a possible reason, that high numbers of diatoms occurred, which may have outcompeted coccolithophores. The composition of the coccolithophore assemblage is different from those off Cap Blanc, but rather similar to those off SW Africa. Emiliania huxleyi overwhelmingly dominated the annual coccolith flux, similar to what is known from the sub-polar North Atlantic further to the north (Andruleit 1997).

In general, E. huxleyi is numerically abundant especially in the North Atlantic region and in the relatively high primary production upwelling region off SW Africa. The lower photic zone species, $F$. profunda, builds up a relatively high portion in the temperate to subtropical but rather oligotrophic areas, which are characterized by annually recurring high production in spring. The region off Cape Blanc stands out in terms of a high proportion of a number of small-sized coccolithophore species and a low diatom production in this area. This assemblage may therefore mirror forcing factors which altered seasonally, upwelling (i.e. nutrient availability, light regime and turbulence) and sea-surface temperature.

\section{Conclusions}

The study of a sediment trap deployed off Cape Blanc for three years revealed a diverse and variable coccolith flux that reflects the prevailing hydrographic conditions of this dynamic offshore upwelling region. A number of conclusions can be drawn.
- Coccolith fluxes vary considerably in temporal distribution and abundance with significantly increased fluxes in winter 1990/1991 (c. 300\%). The assemblage was diverse with 74 species recorded. It revealed strong inter-annual and intraseasonal variations. However, in most samples the dominant species were Emiliania huxleyi, Florisphaera profunda, and Gephyrocapsa spp.. In addition, Ophiaster spp. and Acanthoica spp. added significantly to the fluxes in January/ February 1991. Gladiolithus flabellatus, Umbellosphaera spp., Umbilicosphaera spp., Calcidiscus leptoporus ssp. quadriperforatus and C. leptoporus also characterize the assemblage and were continuously present but in variable abundances, indicating changing surface water conditions.

- During the study period, different intervals were distinguished, characterized by specific assemblages that point towards the variable and changing environmental conditions of the region. At the beginning, a rather constant species composition of the coccolithophore fluxes prevailed, displaying only small changes. Variations in upwelling intensity and in the meandering filaments or small surface water eddies with different water characteristics can explain these minor changes in the coccolithophore assemblage. In winter 1990/1991 a shift towards coccolithophore species of mainly the middle photic zone took place, characterized particularly by a significantly high flux of Ophiaster spp., Acanthoica spp. and small species of Syracosphaera spp.

- Rapid settling is inferred from the good preservation of the small and delicate coccoliths accompanied by an increased occurrence of fragile species, for example, holococcolithophores, in the water column. This fast settling was most probably triggered by increased production in the upper water column, resulting in the 'pulse-like event', before surface water conditions turned to more oligotrophic conditions.

- In general, the combination of environmental parameters rather than distinct single parameters seems to explain the changes in coccolith fluxes. Especially in autumn, the variability of the coccolith fluxes is quite well explained by the variability in SST. In spring the variance in coccolithophore assemblage seems to correspond more strongly with direct nutrient availability, as indicated by the nitrate concentration at $20 \mathrm{~m}$ depth and lithogenic particles. In summer the situation seems more complex. Nutrients and SST have a great influence on the assemblage variance; however, the results also suggest that further environmental variables may play a more important role.

- The observed mean coccolith fluxes off Cape Blanc are well within the range of those in the SW African upwelling as well as in more oligotrophic sites of the temperate North Atlantic and the Canary Islands. However, the assemblage composition is conspicuously different. The region off Cape Blanc stands out in terms of a lower content of E. huxleyi but an enhanced proportion of a number of small-sized coccolithophore species. This probably mirrors forcing factors, which altered seasonally, upwelling (i.e. nutrient availability, light regime and turbulence) and seasurface temperature.

\section{Appendix A: Taxonomic list}

The taxonomic list comprises all taxa encountered in the samples and these are listed in alphabetical order. Full bibliographic references can be found in Young et al. (2003).

Acanthoica Lohmann, 1903

Acanthoica acanthifera Lohmann, 1902 
Acanthoica quattrospina Lohmann, 1903

Algirosphaera robusta (Lohmann, 1902) Norris, 1984

Alisphaera Heimdal, 1973

Alisphaera unicornis Okada \& McIntyre, 1977

Calcidiscus leptoporus (Murray \& Blackman, 1898) Loeblich \& Tappan, 1978

Calcidiscus leptoporus (small type)

Calcidiscus leptoporus ssp. quadriperforatus (Kamptner, 1937)

Geisen et al., 2002

Calciopappus rigidus Heimdal in Heimdal \& Gaarder, 1981

Calciopappus caudatus Gaarder \& Ramsfjell, 1954

Calciosolenia brasiliensis Lohmann, 1919

Calciosolenia murrayi Gran, 1912

Ceratolithus cristatus Kamptner, 1950

Coccolithus pelagicus (Wallich, 1877) Schiller, 1930

Coronosphaera Gaarder in Gaarder \& Heimdal, 1977

Coronosphaera binodata (Kamptner, 1927) Gaarder in Gaarder \& Heimdal, 1977

Coronosphaera mediterranea (Lohmann, 1902) Gaarder in Gaarder \& Heimdal, 1977

Discosphaera tubifera (Murray \& Blackman, 1898) Ostenfeld, 1900

Emiliania huxleyi (Lohmann, 1902) Hay \& Mohler, 1967

Florisphaera profunda Okada \& McIntyre, 1980

Gephyrocapsa ericsonii McIntyre \& Bé, 1967

Gephyrocapsa muellerae Bréhéret, 1978

Gephyrocapsa oceanica Kamptner, 1943

Gladiolithus flabellatus (Halldal \& Markali, 1955) Jordan \&

Chamberlain, 1993

Helicosphaera carteri (Wallich, 1877) Kamptner, 1954

Helicosphaera hyalina Gaarder, 1970

Helicosphaera wallichii (Lohmann, 1902) Okada \& McIntyre, 1977

Hayaster perplexus (Bramlette \& Riedel, 1954) Bukry, 1973

Michaelsarsia elegans Gran, 1912

Oolithotus antillarum (Cohen, 1964) Reinhardt in Cohen \& Reinhardt, 1968

Oolithotus fragilis (Lohmann, 1912) Martini \& Müller, 1972

Ophiaster (Gran, 1912) Manton \& Oates, 1983

Palusphaera Lecal, 1965

Pappomonas Manton \& Oates, 1975

Papposphaera Tangen, 1972

Papposphaera lepida Tangen, 1972

Pontosphaera Lohmann, 1902

Pontosphaera multipora (Kamptner, 1948) Roth, 1970

Reticulofenestra sessilis (Lohmann, 1912) Jordan \& Young, 1990

Rhabdosphaera Haeckel, 1894

Rhabdosphaera clavigera Murray \& Blackman, 1898

Rhabdosphaera stylifer Lohmann, 1902

Rhabdosphaera xiphos (Deflandre \& Fert, 1954) Norris, 1984

Syracosphaera (Lohmann, 1902) Lemmerman, 1903

Syracosphaera ampliora Okada \& McIntyre, 1977

Syracosphaera anthos (Lohmann, 1912) Janin, 1987

Syracosphaera bannockii (Borsetti \& Cati, 1976) Cors et al., 2000

Syracosphaera borealis Okada \& McIntyre, 1977

Syracosphaera corolla Lecal, 1966

Syracosphaera delicata Cros et al., 2000

Syracosphaera dilatata Jordan et al., 1993

Syracosphaera halldalii Gaarder in Gaarder \& Hasle, 1971

Syracosphaera histrica Kamptner, 1941

Syracosphaera lamina Lecal-Schlauder, 1951

Syracosphaera marginaporata Knappertsbusch, 1993

Syracosphaera molischii Schiller, 1925

Syracosphaera nana (Kamptner, 1941) Okada \& McIntyre, 1977

Syracosphaera nodosa Kamptner, 1941

Syracosphaera noroitica Knappertsbusch, 1993
Syracosphaera ossa (Lecal, 1966) Loeblich \& Tappan, 1968

Syracosphaera pirus Halldal \& Markali, 1955

Syracosphaera prolongata Gran, 1912

Syracosphaera pulchra Lohmann, 1902

Syracosphaera rotula Okada \& McIntyre, 1977

Syracosphaera tumularis Sánchez-Suárez, 1990

Tetralithoides quadrilaminata (Okada \& McIntyre, 1977) Jordan, Kleijne \& Heimdal, 1993

Turrilithus Jordan et al., 1991

Umbellosphaera irregularis Paasche in Markali \& Paasche, 1955

Umbellosphaera tenuis (Kamptner, 1937) Paasche in Markali \& Paasche, 1955

Umbilicosphaera anulus (Lecal, 1967) Young \& Geisen, 2003

Umbilicosphaera foliosa (Kamptner, 1963) Geisen in Sáez et al., 2003

Umbilicosphaera hulburtiana Gaarder, 1970

Umbilicosphaera sibogae (Weber-Van Bosse, 1901) Gaarder, 1970

Holococcoliths

Calcidiscus leptoporus ssp. quadriperforatus HOL (Kamptner, 1937) Geisen et al., 2002

Calyptrolithophora papillifera (Halldal, 1952) Heimdal in Heimdal \& Gaarder, 1980

Calyptrosphaera cialdii Borsetti \& Cati, 1976

Helicosphaera HOL dalmaticus type informal

Helicosphaera carteri HOL solid Cros et al., 2000

Homozygosphaera triarcha Halldal \& Markali, 1955

Poritectolithus Kleijne, 1991

Sphaerocalyptra Deflandre, 1952

Syracolithus Deflandre, 1952

Syracolithus schilleri (Kamptner 1927) Loeblich \& Tappan, 1963

Syracosphaera anthos HOL (Lohmann, 1912) Janin, 1987

Syracosphaera bannockii HOL (Borsetti \& Cati, 1976) Cros et al., 2000

Syracosphaera pulchra HOL oblonga type Young et al., 2003

Syracosphaera pulchra HOL pirus type Young et al., 2003

\section{Acknowledgements and Funding}

We are grateful to the officers and crews of R/V Meteor for competent assistance in recovering of the trap deployments. Meral Köbrich was funded by the European Graduate College Proxies of the Earth History (EUROPROX). We thank the reviewers K. Hagino, E. Malinverno and J. Young for valuable recommendations that helped to improve the quality of the manuscript.

\section{Scientific editing by Jeremy Young}

\section{References}

Alvarez-Salgado, X.A., Doval, M.D., Borges, A.V., Joint, M., Frankignoulle, I., Woodward, M. \& Figueiras, F.G. 2001. Off-shelf fluxes of labile materials by an upwelling filament in the NW Iberian Upwelling System. Progress in Oceanography, 5, 321-337, http://doi.org/10.1016/S0079-6611(01)00073-8 Alvarez-Salgado, X.A., Aristegui, J., Barton, E.D. \& Hansell, D.A. 2007. Contribution of upwelling filaments to offshore carbon export in the subtropical Northeast Atlantic Ocean. Limnology and Oceanography, 52, 1287-1292.

Andruleit, H. 1996. A filtration technique for quantitative studies of coccoliths. Micropaleontology, 42, 403-406.

Andruleit, H. 1997. Coccolithophore fluxes in the Norwegian-Greenland Sea: seasonality and assemblage alteration. Marine Micropaleontology, 31, 45-64.

Andruleit, H. 2007. Status of the Java upwelling area (Indian Ocean) during the oligotrophic Northern Hemisphere winter monsoon season as revealed by coccolithophores. Marine Micropaleontology, 64, 36.

Barton, E.D. 1998. Eastern boundary of the North Atlantic: Northwest Africa and Iberia. In: Robinson, A.R. \& Brink, K.H. (eds) The Sea - The Global Coastal Ocean - Regional Studies and Synthesis. John Wiley, New York, 633-657.

Barton, E.D. \& Hughes, P. 1982. Variability of the water masses interlacing off NW Africa. Journal of Marine Research, 40, 963-984.

Baumann, K.-H., Boeckel, B. et al. 2004. Contribution of calcareous plankton groups to the carbonate budget of South Atlantic surface sediments. In: Wefer, G., Mulitza, S. \& Rathmeyer, V. (eds) The South Atlantic in the Late 
Quaternary - Reconstruction of Material Budgets and Current Systems. Springer Verlag, Berlin, 81-99.

Baumann, K.-H., Andruleit, H., Böckel, B., Geisen, M. \& Kinkel, H. 2005. The significance of extant coccolithophores as indicators of ocean water masses, surface water temperature, and paleoproductivity: A review. Paläontologische Zeitschrift, 79, 93-112.

Beaufort, L. \& Heussner, S. 1999. Coccolithophorids on the continental slope of the Bay of Biscay - production, transport and contribution to mass fluxes. Deep-Sea Research II, 46, 2147-2174.

Boeckel, B. \& Baumann, K.-H. 2008. Vertical and lateral variations in coccolithophore community structure across the subtropical frontal zone in the South Atlantic Ocean. Marine Micropaleontology, 67, 255-273.

Broerse, A., Ziveri, P., van Hinte, J.E. \& Honjo, S. 2000. Coccolithophore export production, species composition, and coccolith $\mathrm{CaCO}_{3}$ fluxes in the NE Atlantic $\left(34^{\circ} \mathrm{N} 21^{\circ} \mathrm{W}\right.$ and $\left.48^{\circ} \mathrm{N} 21^{\circ} \mathrm{W}\right)$. Deep-Sea Research II, 47, 1877-1905.

Carr, M.-E. 2002. Estimation of potential productivity in Eastern Boundary Currents using remote sensing. Deep-Sea Research II, 49, 59-80.

Cortes, M.Y., Bollmann, J. \& Thierstein, H.R. 2001. Coccolithophore ecology at the HOT station ALOHA, Hawaii. Deep-Sea Research II, 48, 1957-1981.

Dutkiewicz, S., Follows, M., Marshall, J. \& Gregg, W.W. 2001. Interannual variability of phytoplankton abundances in the North Atlantic. Deep-Sea Research Part II, 48, 2323-2344.

Fischer, G. \& Karakas, G. 2009. Sinking rates of particles in biogenic silicaand carbonate-dominated production systems of the Atlantic Ocean: implications for the organic carbon fluxes to the deep ocean. Biogeosciences, 6 , $85-102$.

Fischer, G., Donner, B., Ratmeyer, V., Davenport, R. \& Wefer, G. 1996. Distinct year-to-year particle flux variations off Cape Blanc during 19881991: Relation to $\mathrm{d}^{18} \mathrm{O}$-deduces sea-surface temperatures and tradewinds. Journal of Marine Research, 54, 73-98.

Fischer, G., Karakas, G. et al. 2007. Mineral ballast and particle settling rates in the coastal upwelling system off NW Africa and the South Atlantic. International Journal of Earth Sciences (Geologische Rundschau), 98, 281298, http://doi.org/10.1007/s00531-007-0234-7

Gabric, A.J., Garcia, L., van Camp, L., Nykjær, L., Eifler, W. \& Schimpf, W. 1993. Offshore export of shelf production in the Cape Blanc (Mauretania) filament as described from coastal zone color scanner imagery. Journal of Geophysical Research, 98, 4697-4712.

Giraudeau, J. \& Bailey, G.W. 1995. Spatial dynamics of coccolithophore comunities during an upwelling event in the Southern Benguela system. Continental Shelf Research, 15, 1825-1852.

Giraudeau, J., Monteiro, P.M.S. \& Nikodemus, K. 1993. Distribution and malformation of living coccolithophores in the northern Benguela upwelling system off Namibia. Marine Micropaleontology, 22, 93-110.

Hagino, K., Okada, H. \& Matsuoka, H. 2000. Spatial dynamics of coccolithophore assemblages in the Equatorial Western-Central Pacific Ocean. Marine Micropaleontology, 39, 53-72.

Haidar, A.T. \& Thierstein, H.R. 2001. Coccolithophore dynamics off Bermuda (N. Atlantic). Deep-Sea Research II, 48, 1925-1956.

Haidar, A.T., Thierstein, H.R. \& Deuser, W.G. 2000. Calcareous phytoplankton standing stocks, fluxes and accumulation in Holocene sediments off Bermuda (N. Atlantic). Deep-Sea Research II, 47, 1907-1938.

Honjo, S. 1976. Coccoliths: production, transportation and sedimentation. Marine Micropaleontology, 1, 65-79.

Incarbona, A., Martrat, B., Di Stefano, E., Grimalt, J.O., Pelosi, N., Patti, B. \& Tranchida, G. 2010. Primary productivity variability on the Atlantic Iberian Margin over the last 70,000 years: Evidence from coccolithophores and fossil organic compounds. Paleoceanography, 25, PA2218, http://doi. org/10.1029/2008PA001709

Johnson, J. \& Stevens, I. 2000. A fine resolution model of the eastern North Atlantic between the Azores, the Canary Islands and the Gibraltar Strait. Deep-Sea Research I, 47, 875-899.

Jordan, R.W. \& Winter, A. 2000. Assemblages of coccolithophorids and other living microplankton off the coast of Puerto Rico during January-May 1995. Marine Micropaleontology, 39, 113-130.

Kinkel, H., Baumann, K.-H. \& Cepek, M. 2000. Coccolithophores in the equatorial Atlantic Ocean: Response to seasonal and Late Quaternary surface water variability. Marine Micropaleontology, 39, 87-112.

Köbrich, M. \& Baumann, K.-H. 2009. Coccolithophore flux in a sediment trap off Cape Blanc (NW-Africa). Journal of Nannoplankton Research, 30, 83-96.

Kostianoy, A.G. \& Zatsepin, A.G. 1996. The West African coastal upwelling filaments and cross-frontal water exchange conditioned by them. Journal of Marine Systems, 7, 349-359.

Lange, C.B., Romero, O.E., Wefer, G. \& Gabric, A.J. 1998. Offshore influence of coastal upwelling off Mauritania, NW Africa, as recorded by diatoms in sediment traps at $2195 \mathrm{~m}$ water depth. Deep-Sea Research I, 45, 985-1013.

Lathuilière, C., Echevin, V. \& Lévy, M. 2008. Seasonal and intraseasonal surface chlorophyll- $a$ variability along the northwest African coast. Journal of Geophysical Research, 113, http://doi.org/10.1029/2007JC004433

Lepš, J. \& Šmilauer, P. 2003. Multivariate Analysis of Ecological Data Using CANOCO. Cambridge University Press, Cambridge.
Marchesiello, P., Herbette, S., Nykjaer, L. \& Roy, C. 2004. Eddy-driven dispersion processes in the Canary Current upwelling system: comparison with the California system. Globec International Newsletter, 10, 5-7.

Meunier, T., Barton, E.D., Barreiro, B. \& Torres, R. 2012. Upwelling filaments off Cap Blanc: Interaction of the NW African upwelling current and the Cape Verde frontal eddy field? Journal of Geophysical Research, 117, C08031, http://doi.org/10.1029/2012JC007905

Mittelstaedt, E. 1991. The boundary along the northwest African coast. Progress in Oceanography, 26, 307-355.

Müller, P.J. \& Fischer, G. 2001. A 4-year sediment trap record of alkenones from the filamentous upwelling region off Cape Blanc, NW Africa and a comparison with distributions in underlying sediments. Deep-Sea Research I, 48, 1877-1903.

Nowald, N., Karakas, G., Ratmeyer, V., Fischer, G., Schlitzer, R., Davenport, R.A. \& Wefer, G. 2006. Distribution and transport processes of marine particulate matter off Cape Blanc (NW-Africa): Results from vertical camera profiles. Ocean Science Discussions, 3, 903-938.

Nykjær, L. \& van Camp, L. 1994. Seasonal and interannual variability of the coastal upwelling along northwest Africa and Portugal from 1981 to 1991. Journal of Geophysical Research, 99, 14197-14207.

Ohde, T. \& Siegel, H. 2010. Biological response to coastal upwelling and dust deposition in the area off Northwest Africa. Continental Shelf Research, 30 , 1108-1119.

Okada, H. \& Honjo, S. 1973. The distribution of oceanic coccolithophorids in the Pacific. Deep-Sea Research, 20, 355-367.

Pelegrí, J.L., Arístegui, J. et al. 2005. Coupling between the open ocean and the coastal upwelling region off northwest Africa: Water recirculation and offshore pumping of organic matter. Journal of Marine Systems, 54, 3-37.

Probert, I., Fresnel, J., Billard, C., Geisen, M. \& Young, J.R. 2007. Light and electron microscope observations of Algirosphaera robusta (Prymnesiophyceae) Journal of Phycology, 43, 319-332.

Ramaswamy, V. \& Gaye, B. 2006. Regional variations in the fluxes of foraminifera carbonate, coccolithophorid carbonate and biogenic opal in the northern Indian Ocean. Deep-Sea Research I, 53, 271

Ratmeyer, V., Fischer, G. \& Wefer, G. 1999. Lithogenic particle fluxes and grain size distributions in the deep ocean off northwest Africa: Implications for seasonal changes of aeolian dust input and downward transport. DeepSea Research I, 46, 1289-1337.

Romero, O.E., Boeckel, B., Donner, B., Lavik, G., Fischer, G. \& Wefer, G. 2002. Seasonal productivity dynamics in the pelagic central Benguela System inferred from the flux of carbonate and silicate organisms. Journal of Marine Systems, 37, 229-307.

Speth, P., Detlefsen, H. \& Sierts, H.-W. 1978. Meterological influences on upwelling off northwest Africa. Deutsche Hydrografische Zeitung, 31, 95-104.

Sprengel, C., Baumann, K.-H. \& Neuer, S. 2000. Seasonal and interannual variation of coccolithphore fluxes and species composition in sediment traps north off Gran Canaria $\left(29^{\circ} \mathrm{N} 15^{\circ} \mathrm{W}\right)$. Marine Micropaleontology, 39, 157-178.

Sprengel, C., Baumann, K.-H., Henderiks, J., Henrich, R. \& Neuer, S. 2002. Modern coccolithophore and carbonate sedimentation along a productivity gradient in the Canary Islands region: Seasonal export production and surface accumulation rates. Deep-Sea Research II, 49, 3577-3598.

Stoll, H.M., Arevalos, A., Burke, A., Ziveri, P., Mortyn, G., Shimizu, N. \& Unger, D. 2007. Seasonal cycles in biogenic production and export in Northern Bay of Bengal sediment traps. Deep-Sea Research II, 54, 558-580.

Townsend, D.W., Keller, M.D., Holligan, P.M., Ackleson, S.G. \& Balch, W.M. 1994. Blooms of the coccolithophore Emiliania huxleyi with respect to hydrography in the Gulf of Maine. Continental Shelf Research, 14, 979-1000.

Triantaphyllou, M.V., Ziveri, P. \& Tselepides, A. 2005. Coccolithophore export production and response to seasonal surface water variability in the oligotrophic Cretan Sea (NE Mediterranean). Micropaleontology, 50, 127-144.

Turner, J.T. 2002. Zooplankton fecal pellets, marine snow and sinking phytoplankton blooms. Aquatic Microbial Ecology, 27, 57-102.

van Camp, L., Nykjær, L., Mittelstaedt, E. \& Schlittenhardt, P. 1991. Upwelling and boundary circulation off Northwest Africa as depicted by infrared and visible satelite observations. Progress in Oceanography, 26, 357-402.

van Wijngaarden, R., van den Brink, P.J., Voshaar, J.H.O. \& Leeuwangh, P. 1995. Ordination techniques for analysing response of biological communities to toxic stress in experimental ecosystems. Ecotoxicology, 4, 61-77.

Westbroek, P., Brown, C.W. et al. 1993. A model approach to biological climate forcing: The example of Emiliania huxleyi. Global and Planetary Change, 8, 27-46.

Winter, A. \& Martin, K. 1990. Late Quaternary history of the Agulhas Current. Paleoceanography, 5, 479-486.

Young, J., Geisen, M., Cros, L., Kleijne, A., Sprengel, C., Probert, I. \& Østergaard, J. 2003. A guide to extant coccolithophore taxonomy. Journal of Nannoplankton Research Special Issue, 1, 1-125.

Ziveri, P., Rutten, A., de Lange, G., Thomson, J. \& Corselli, C. 2000. Presentday coccolith fluxes recorded in central eastern Mediterranean sediment traps and surface sediments. Palaeogeography, Palaeoclimatology, Palaeoecology, 158, 175-195.

Ziveri, P., de Bernardi, B., Baumann, K.-H., Stoll, H.M. \& Mortyn, P.G. 2007. Sinking of coccolith carbonate and potential contribution to organic carbon ballasting in the deep ocean. Deep-Sea Research II, 54, 659. 
GESFACETS.

from ELSEVIER

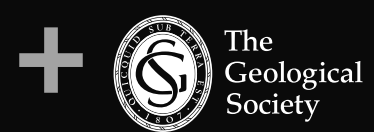

serving science $\mathcal{E}$ profession
The Geofacets-GSL Millennium Edition
Geofacets from Elsevier is an innovative web-based research tool designed by geoscientists for geoscientists. Elsevier and the Geological Society of London (GSL) have partnered together to provide GSL members with a unique opportunity to gain individual access to thousands of geological maps from the renowned Lyell Collection through the Geofacets platform.

http://www.geolsoc.org.uk/geofacets

\section{GEOFACETS ENHANCES A GEOSCIENTIST'S WORKFLOW THROUGH FOUR UNIQUE CAPABILITIES:}

\section{DISCOVERABILITY:}

Search for geological maps geographically or by keyword on an interactive map interface

\section{AGGREGATED, CURATED CONTENT:}

Search results based on indexing thousands of maps extracted from the Lyell Collection

\section{CONTEXT AND INSIGHT:}

Individual map details contain source article information, including a read-only PDF of the source article

\section{INTEGRATION:}

Maps are easy to integrate into GIS, presentation software, and other analysis tools

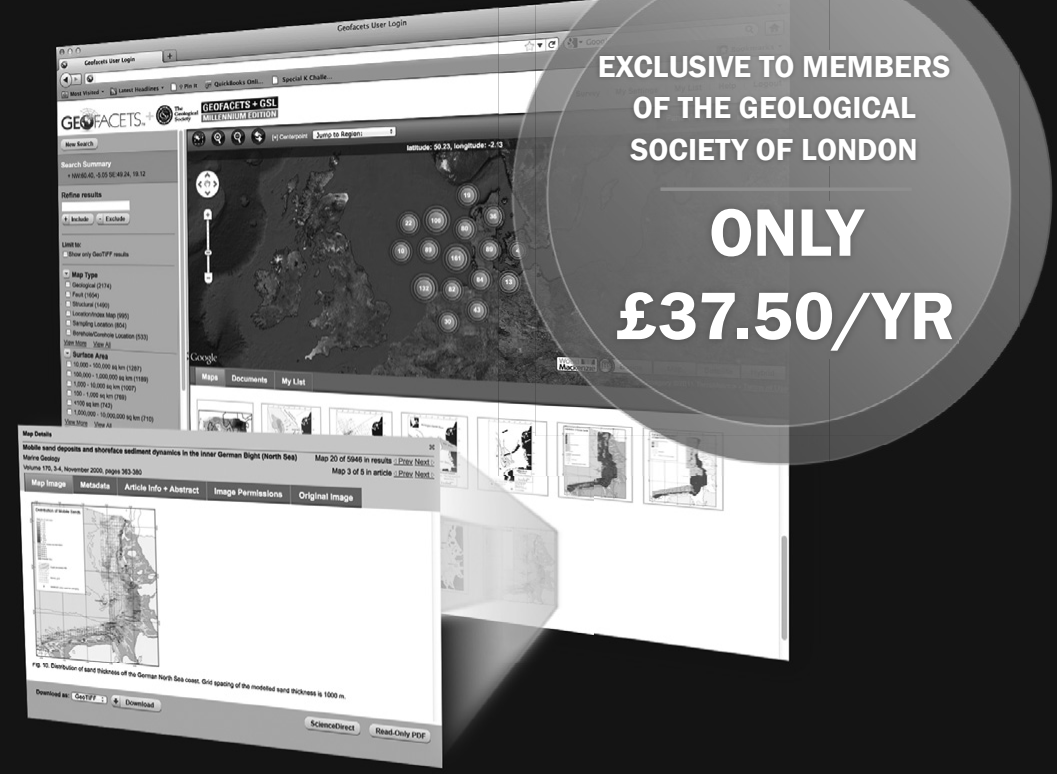

SUPERCHARGE YOUR GSL MEMBERSHIP WITH

THE GEOFACETS-GSL MILLENNIUM EDITION.

Email membership@geolsoc.org.uk to sign up today!

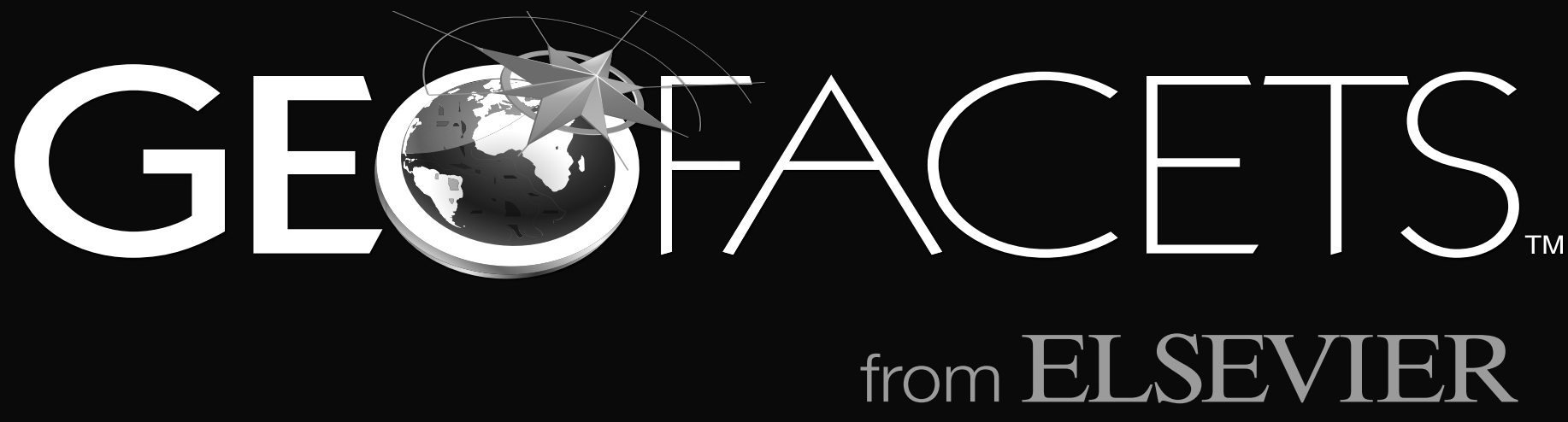

